\title{
Agnieszka Kluba Peiper w Madrycie, czyli hiszpański topos
}

\begin{abstract}
Kluba Agnieszka, Peiper w Madrycie, czyli hiszpański topos [Peiper in Madrid or the Spanish topos]. „Przestrzenie Teorii” 17. Poznań 2012, Adam Mickiewicz University Press, pp. 163-195. ISBN 978-83-232-2449-5. ISSN 1644-6763.

The pope of Polish avant-garde is a main character of a certain persistently recollected critical topos. It claims that, after spending World War I in Europe, Tadeusz Peiper took a basic shape of his poetical idea from avant-garde artists he then met. Critics who share this opinion believe that Peiper, aware of these "borrowings", was developing a carefully planned strategy in order to conceal those external sources and to pretend originality. The author of the article disavows these harmful assumptions, reconstructing their possible genesis (rooted in and continued prewar suspicions of plagiarism) and analyzing some of their critical versions. In the same time she presents wider and not only avant-garde background of Peiper's idea (baroque, gongorism).
\end{abstract}

Temat związków Tadeusza Peipera z Hiszpanią to jeden z toposów polskiego literaturoznawstwa ${ }^{1}$ - topos szczególny, dzięki któremu rozważana zazwyczaj w abstrakcyjnym epoché teoria języka poetyckiego odnajduje się nagle w nietypowym dla siebie porządku, tuż obok faktów, biografii, historii (mitów, mistyfikacji, legend)...

Składa się na ten topos kilka elementów. Po pierwsze (rzekomo) skąpa liczba informacji o szczegółach pobytu poety w Madrycie w latach 1914-1921. Po drugie rozmaicie interpretowana „powściągliwość” autora Nowych ust w opisywaniu hiszpańskiego doświadczenia. Po trzecie (domniemana) zależność programowych postulatów twórcy „Zwrotnicy” oraz jego wierszy od dokonań teoretycznych i poetyckich autorów iberyjskich.

1 Zob. A.K. Waśkiewicz, Epizod hiszpański Tadeusza Peipera, „Kultura” 1971, nr 11; C. Marrodan Casas, Tadeusz Peiper a ultraizm hiszpański, „Współczesność” 1971, nr 13; S. Jaworski, U podstaw awangardy. Tadeusz Peiper pisarz i teoretyk, Kraków 1968, s. 4446; B. Carpenter, The Cracow Avant-garde oraz Tadeusz Peiper, [w:] taż, The poetic avantgarde in Poland, 1918-1939, Seattle-London 1983; G. Makowiecka, Peiper i inni w Madrycie, [w:] taż, Po drogach polsko-hiszpańskich, Kraków 1984; M. Delaperrière, Huidobro et Peiper: affinités et divergences, [w:] taż, Les Avant-Gardes polonaises et la Poésie européenne: étude sur l'imagination poétique, Paris 1991, polskie tłumaczenie: Polskie awangardy a poezja europejska. Studium wyobraźni poetyckiej, przeł. A. Dziadek, Katowice 2004; E. Quintana, E. Palka, Huidobro, Borges y las primeras traducciones ultraístas al polaco (1922), „Cuadernos Hispanoamericanos” 1995, nr 541-542; E. Palka, El periodo espagñol en la vida y creación de Tadeusz Peiper, un intento de reconstrucción, [w:] Europa del centro y del este y el mundo hispanico. Simposio Internacional de Hispanistas. Cracovia 26-28 de octubre de 1995, red. B. Picado y T. Eminowicz, Kraków 1996; B. Lentas, Tadeusz Peiper w Hiszpanii, Gdańsk 2011. 
Po czwarte malownicze atrybuty dodatkowe, tj. historia zagubionej walizki, zawierającej rękopisy oraz... broda, jakoby hiszpańska. Wspominał Przyboś:

[...] czarna spiczasta bródka była aluzją do jego hiszpańskości, chcę rzec: do jego wieloletniego pobytu w czasie wojny w Hiszpanii (kształt tej bródki on potem inaczej tłumaczył, ale i dla mnie, i dla moich kolegów z uniwerku owiewał ją legendą gorący wiatr Madrytu)2.

Nie inaczej zapamiętał Ważyk:

W tym czasie bród nie noszono, a broda Peipera była legendarna ${ }^{3}$.

On sam w zakończeniu Tędy (1930) stanowczo zaprzeczał:

Nosiłem wówczas brodę, a że przyjechałem z Hiszpanii, uważano ją za brodę hiszpańską, podczas gdy kształt jej wynikał najściślej z kształtu mojej twarzy

I dodaje:

To samo było z moją literaturą.

Domysły, że idee Peipera nie urodziły się ex nihilo i że mogły kształtować się podczas pobytu twórcy „Zwrotnicy” w krajach, które wcześniej niż ziemie polskie ogarnął awangardowy ferment, pojawiały się od początku. Peiper znowu ripostował:

Mrugacze, nie cieszcie się; moje idee, choć wiezione z zagranicy, nie były ideami zagranicy. Miałem je już dawno w sobie. Trzeba było z nakazów własnej natury, z odruchów, z popędów, stronić w latach chłopięcych od sztuki, którą wokół wielbiono, aby potem w wieku dojrzałości rodzić nową myśl i nowy świat. Zagranica była dla mnie głównie świadectwem słuszności moich popędów. A jeśli była także nauką, to inną niż to sobie wyobrażają importerzy. Choć szumieć będzie moje wyznanie, nie mogę nie powiedzieć, że zarówno w Niemczech, jak i we Francji, badałem tajemnicę powstawania wielkich kultur. W odróżnieniu od wielu moich ziomków, nie jechałem do Berlina czy Paryża po to, aby tam zakupić jakąś nową idejkę, lecz by poznać powstawanie laboratoriów ideowych i to poznanie zużytkować potem w kraju przy tworzeniu krajowej pracowni idei. Nie oberwanie gałązki było celem mojej podróży, lecz wiedza o tym, jak rosną lasy ${ }^{5}$.

2 J. Przyboś, „Zwrotnica” Tadeusza Peipera, [w:] tenże, Sens poetycki, t. 1, Kraków 1967, s. 164.

${ }^{3}$ A. Ważyk, Kwestia gustu, Warszawa 1966, s. 76.

4 T. Peiper, Tędy. Artykuty, Warszawa 1930. Cyt. za T. Peiper, Pisma, oprac. tekstu i redakcja T. Podoska, t. 1: Tędy. Nowe usta, przedmowa, komentarz, nota biograficzna S. Jaworski, Kraków 1972, s. 316; dalej przywoływane jako T. Peiper, Tędy. Nowe usta. Także w wydaniu Pism wybranych Peipera w 1979 roku Stanisław Jaworski zapewnia czytelnika: „Brodę nosił Peiper jeszcze przed przybyciem do Hiszpanii, podczas pobytu we Francji” (Wrocław 1979, s. 187).

5 T. Peiper, Tędy. Nowe usta, s. 313. 
Skrupulatni badacze wielokrotnie zauważali, że w tej wypowiedzi (pisanej w roku 1929 lub 1930 jako Zakończenie do Tędy) pominął Hiszpanię i uznawali to pominięcie za unik ${ }^{6}$. Miał, ich zdaniem, potwierdzać celową strategię dezinformacyjną autora $T e ̨ d y$, chcącego rzekomo zamaskować hiszpańskie tropy. Tymczasem w tymże Zakończeniu, choć nieco dalej, nawiązuje Peiper do artykułu o młodych poetach hiszpańskich ${ }^{7}$ i wyjaśnia okoliczności jego opublikowania w „Nowej Sztuce”:

Artykuł o nowej poezji hiszpańskiej był pierwszym, jaki z zakresu literatury opublikowałem w kraju. Był on dla mnie pretekstem do poruszenia spraw, na których mi zależało. [...] Artykuł o cudzych sprawach był mi na rękę, bo mogłem w nim wypowiedzieć w sposób mniej obowiązujący kilka moich myśli. To zrobiłem. Ująłem poezję hiszpańską z mojego punktu widzenia i zupełnie inaczej, niż to czynili w swych wynurzeniach jej twórcy, z których zresztą żadnego osobiście nie znałem. Nawet na przekładach znać ślady moich upodobań, już choćby w bezceremonialnych skreśleniach, którym poddałem oryginały ${ }^{8}$.

Zazwyczaj w analizach tego fragmentu skupiano się na dowodzeniu, że miał się Peiper rozmyślnie mijać z prawdą, kiedy odżegnywał się - już po raz kolejny ${ }^{9}$ - od osobistej znajomości z awangardowymi twórcami. Mniejszą wagę przykładano do zasadniczej myśli, którą próbował Peiper przekazać - że w istocie wykorzystał komentarz towarzyszący opublikowanym w 1922 roku tłumaczeniom jako okazję, aby po raz pierwszy wypowiedzieć publicznie własne poetologiczne przeświadczenia. Dlatego zbieżność między sformułowaniami użytymi w tej publikacji a tymi, którymi posłużył się w późniejszych tekstach programowych ${ }^{10}$, interpreto-

${ }^{6}$ Zob. A.K. Waśkiewicz, Epizod hiszpański Tadeusza Peipera, s. 3.

7 T. Peiper, Nowa poezja hiszpańska, „Nowa Sztuka” 1922, z. 2.

8 Tenże, Tędy. Nowe usta, s. 314.

9 Por. jego odpowiedź w wywiadzie przeprowadzonym przez Mariana Czuchnowskiego (W ambasadzie awangardy, „Głos Narodu” 1929, nr 9): „- Czy Pan zna osobiście awangardzistów zagranicznych i których? - Mimo kilkuletniego pobytu za granicą żadnego $\mathrm{z}$ tamtejszych awangardzistów osobiście nie znam. Zresztą w owych latach przedwojnia i wojny nie interesowałem się wcale sztuką awangardy. W Paryżu zajmowałem się historią teatru, a Apollinaire'a nie znałem nawet z nazwiska. W Madrycie spędzałem dnie na czytaniu prasy, śledzeniu etapów wojny i przepowiadaniu wyniku. Pozyskanie awangardzistów zagranicznych do współpracy w «Zwrotnicy» udało mi się dzięki uprzejmości osiadłego w Paryżu krakowianina Kiplinga, który - jak wiadomo - jest jednym z najsławniejszych malarzy współczesnej Europy”. Cyt. za T. Peiper, Pisma, oprac. tekstu i redakcja T. Podoska, t. 2: O wszystkim i jeszcze o czymś. Artykuły, eseje, wywiady (1918-1939), przedmowa, komentarz i bibliografia S. Jaworski, Kraków 1974, s. 190; dalej przywoływane jako T. Peiper, $O$ wszystkim i jeszcze o czymś...

$10 \mathrm{~W}$ artykule Nowa poezja hiszpańska pisze: „Nieraz [...] zdanie zrywa zupełnie kontakt ze światem rzeczywistym. Powstają wtedy obrazy, którym nic rzeczywistego nie odpowiada, a które posiadają jakąś nieodporną siłę sugestywną". Cyt. za T. Peiper, 
wano głównie jako dowód na powtarzanie przez niego czyichś idei, a nie przejaw ich przemyślenia i dalszych samodzielnych poszukiwań... Nie przeprowadzono głębszej analizy, wykraczającej poza poziom oczywistych podobieństw. Tymczasem tym, co uderza w sposobie, w jaki Peiper przedstawia dokonania młodych twórców z Hiszpanii, jest nieskrywana ambiwalencja. Już początek wydaje się zastanawiający. Komentator zauważa, że nowa poezja hiszpańska „nie ma potrzeby określenia swojego stosunku do życia środowiska” 11 , „nie walczy z przeszłością narodu i nie walczy o przyszłość świata”, a w dodatku „operuje bardzo często tematami muzealnymi”. I choć ostatecznie ten pierwszy, wprowadzający akapit przechodzi w pochwałe „troski o literaturę”, „chwalebnej troski o wartości czysto literackie poezji” 12 oraz uznania dla wiary w „nowe piękno literackie" (zaszczepionej Hiszpanom przez Vicente'a Huidobrę), inicjalne uwagi sformułowane przez autora hasła o „uścisku z rzeczywistością" nie tracą swojego dwuznacznego sensu... Ambiwalentna aura obowiązuje do końca artykułu. W finale poznajemy zaletę i wadę efektu, który charakteryzuje, zdaniem Peipera, przedstawianą poezję i łączy się bezpośrednio z jej cechą szczególną, tj. „szeroką autonomią [zdania] w stosunku do rzeczywistości”. Konsekwencją tej autonomii jest „brak strumienia ciągłości”13 i „rozbicie na człony”, tj. zdania leżące „równorzędnie obok siebie”. Taka „dezartykulacja utworów” pozwala, w opinii komentatora, osiągnąć większą „gęstość” znaczeniową utworów, pozbawionych zbędnych łączników, „przejść" między zdaniami, ale zarazem stwarza ryzyko „dowolności” oraz „utraty jedności organicznej”14.

O wszystkim $i$ jeszcze o czymś..., s. 79. Napotykamy niemal identyczną frazę w artykule Peipera pt. Metafora teraźniejszości z tego samego 1922 roku. Czytamy w nim: „Metafora jest samowolnym spokrewnianiem pojęć, jest tworzeniem związków pojęciowych, którym w świecie realnym nic nie odpowiada”. Cyt. za T. Peiper, Tędy. Nowe usta, s. 54-55.

11 T. Peiper, Nowa poezja hiszpańska. Cyt. za T. Peiper, O wszystkim i jeszcze o czymś..., ten i następne cytaty ze s. 78 .

12 Tamże, ten i następne cytaty ze s. 79 .

13 Tamże, ten i następne cytaty ze s. 80 .

14 Uwagi Peipera umieścić można w nurcie refleksji towarzyszącej rozwojowi wolnego wiersza. Choć twórca „Zwrotnicy” nie przywoływał tego kontekstu, jego spostrzeżenia na temat uwolnionego, tj. traktowanego jako samodzielna jednostka zdania zapowiadają analizy (podejmowane przez badaczy poezji dużo później) skutków autonomizowania się całości składniowych (a więc m.in. dostrzeganego przez Peipera „rozbicia na człony” i „dezartykulacji utworów") w nowej sytuacji poetyckiej wytworzonej przez powstanie wolnego wiersza. Por. np. opinię Clive'a Scotta (The Prose Poem and Free Verse, [w:] Modernizm 1890-1930, red. M. Bradbury, J. McFarlane, London 1991, s. 361-362) „[...] gramatyczne całości, frazy i zdania składowe, tak często traktowane przez rytm i rym bez szacunku w wierszu regularnym - tak, jak gdyby gramatyka była krnąbrną materią, którą poezja powinna poskromić, aby uwolnić swoje [rzekomo] ukryte znaczenia - stały się właściwą podstawą rytmiczną [wolnego] wiersza. Poeci tak troskliwie zaczęli chronić nienaruszal- 
Już z tej pierwszej publikacji wyczytać można zapowiedź wątków, które Peiper podejmie niedługo w artykułach programowych: 1) przeciwstawienie zdań - słowom, 2) niejednoznaczną ocenę jukstapozycji, odpowiedzialnej za to, że między zdaniami ,istnieje [...] jedynie pajęczynowy pomost ogólnej idei" (ze stanowczym sprzeciwem wobec figury zestawienia wystąpi za kilka lat, kiedy środowisko „Almanachu Nowej Sztuki” uzna ją za główny trop), 3) potrzebę szukania sposobu, który pozwoliłby zachować „jedność organiczną” mimo posługiwania się „pięknymi zdaniami”, czyli samowystarczalnymi poetycko całościami syntaktycznymi (jak wiadomo rozwiązaniem zaproponowanym przez Peipera była idea poezja jako budowa oraz koncepcja poematu rozkwitającego)... Ten uchwycony w skrócie katalog podstawowych dla autora Nowych ust spraw, choć z pewnością nie wyczerpuje wszystkich zaprzątających go tematów, dowodzi, że już w 1922 roku miał dość wyrazistą wizję, czym powinna być „nowa poezja polska” i że koncepcja ta klarowała się nie bez polemicznego nawiązania do „nowej poezji hiszpańskiej”. W istocie tym, czego brakowało współczesnym Peiperowi krytykom ${ }^{15}$ i czego nadal nie uwzględniają dzisiejsi badacze podejmujący temat związków pisarza $\mathrm{z}$ zachodnimi awangardami, jest przyjęcie perspektywy intertekstualnej. Z tego punktu widzenia ewentualne „zależności” twórcy „Zwrotnicy” od innych twórców - poetów, teoretyków, filozofów, malarzy - których napotkał podczas swojej wieloletniej wędrówki po Europie, tracą sensacyjny charakter i okazują się przejawem całkiem zwyczajnych, choć subtelnych, zjawisk zachodzących między twórczymi osobowościami (i ogłaszanymi przez nie tekstami)... Przywołany przed chwilą artykuł oraz inne wypo-

ność gramatycznych całostek, że owe całostki wyrosły ponad zdania, w których się pojawiły; fraza przestała być frazą i stała się linijką w poezji, każda część zdania zaczęła domagać się prawa do gramatycznej absolutności albo, mówiąc inaczej, do kierowania się własnym porządkiem, oznaczającego niechętne wchodzenie w obręb zdania i niezależność w decydowaniu o sobie".

15 To uogólnienie, jak każde, można skorygować; w 1921 roku ukazała się książka $O$ wplywach $i$ zależnościach $w$ literaturze Wacława Borowego (wcześniej, w grudniu 1920 roku, drukowana w odcinkach w „Rzeczypospolitej”) dowodząca subtelności autora w rozumieniu delikatnej materii wzajemnych oddziaływań twórców - subtelności, która nie stała się wszakże tym samym od razu udziałem krytyki... Jak zauważał sam autor (O wplywach i zależnościach $w$ literaturze, Warszawa 1921, s. 3-4): „Nikt - prócz samotnie pracujących filologów - nie zwracał uwagi na to, że literatura - przy wszystkich swoich bezpośrednich związkach z życiem jest sztuką [podkreślenia tu i dalej autora] o swoistej technice, że w tej technice są tradycje i kierunki, że więc całe grupy dzieł muszą mieć słabsze lub silniejsze podobieństwa względem siebie. Na zrozumieniu doniosłości czynnika technicznego w literaturze oparte są i dzisiejsze dociekania «genetyczne» naszych uczonych. Dla zasady tych dociekań nie potrafili oni jeszcze pozyskać szerszych kręgów inteligentnej publiczności [...]". 
wiedzi pisarza inaugurujące jego działalność po powrocie do Polski świadczą o tym, że nie miał skłonności do zacierania śladów owych „wpływów”. Gdyby tak było, ominąłby nazwisko Huidobry w artykule o młodych poetach hiszpańskich. A jednak przywołuje go i ma to przywołanie wszelkie znamiona alegacji. W dodatku w tym samym drugim numerze „Nowej Sztuki” przedrukowuje list, który otrzymał od twórcy kreacjonizmu $\mathrm{z}$ autorskim wykładem tej koncepcji, a w dziale Ksiażki $i$ czasopisma wymienia „UUltrę» - pismo hiszpańskiej awangardy literackiej”. To samo - wzmiankę o liście od Huidobry oraz wykaz otrzymanych książek i czasopism - powtórzy w ostatnim numerze pierwszej serii „Zwrotnicy” w październiku 1923 roku. Trudno interpretować te decyzje jako przejaw chęci zacierania śladów... Komentatorzy optujący za taką interpretacją powołują się jednak głównie na późniejsze wypowiedzi pisarza - z końca lat dwudziestych. Jeśli rzeczywiście uznać, że z czasem tę otwartą i pełną entuzjazmu postawę zastąpił Peiper bardziej wstrzemięźliwą, prawdopodobne wydają się co najmniej dwie okoliczności tłumaczące tę zmianę.

Pierwsza łączy się z nie całkiem oczywista - wbrew opiniom badaczy i świadków epoki - sprawą relacji Peipera i Huidobry, tak w planie przeświadczeń teoretycznych, jak i osobistych związków. Wiele wyczytać można na ten temat $\mathrm{z}$ korespondencji, a dokładnie - z czterech ocalałych listów Polaka do Chilijczyka ${ }^{16}$. Już w pierwszym, datowanym na kwiecień 1921 roku, użyta przez Peipera na początku listu formuła daje do myślenia. Przyszły twórca "Zwrotnicy” zwraca się do swojego adresata w następujący sposób: „Mój drogi przyjacielu (Niech Pan pozwoli, błagam Pana, bym się tak do Pana zwracał)!"17. Chętnie powtarzana przez komentatorów „hiszpańskiego epizodu Peipera” teza o jego przyjaźni18 z twórcą kreacjonizmu traci w świetle tych słów rację bytu. „Mi querido amigo" okazuje się konwencjonalnym znakiem, użytym w funkcji przypodobania się odbiorcy, zachęty do odwzajemnienia sympatii. Choć polski pisarz bezsprzecznie cenił swojego korespondenta i pragnął zapewne przede wszystkim dać wyraz swojemu uznaniu, nie pisał całkiem bezinteresownie. Liczył na podtrzymanie intelektualnego kontaktu („[...] daje mi Pan wolność w zadawaniu Panu pytań. Dlatego: co Pan myśli o ultraizmie i jaki jest Pański stosunek do poezji Apollinaire'a?"19) oraz - na dalsze otrzymywanie publikacji Huidobry. Lektura listów Peipera ujaw-

${ }^{16}$ Własność Fundación de Vicente Huidobro, Santiago de Chile.

${ }^{17}$ Cyt. za B. Lentas, Tadeusz Peiper w Hiszpanii, s. 161.

18 A. Wat, Mój wiek. Pamiętnik mówiony, rozmowy prowadził i przedmową opatrzył C. Miłosz, do druku przygotowała L. Ciołkoszowa, cz. 1, Warszawa 1980, s. 40.

19 Cyt. za B. Lentas, Tadeusz Peiper $w$ Hiszpanii, s. 164 (Aneks 2. Korespondencja Tadeusza Peipera $z$ Vicentem Huidobro). 
nia, że zarówno pochwała, jak i plany zacieśnienia intelektualnej przyjaźni nie bardzo się udały. Wprawdzie ostatni list z sierpnia 1922 roku dowodzi, że polski pisarz doczekał się w końcu upragnionej przesyłki z niesprecyzowanymi „publikacjami”, ale dwa wcześniejsze listy świadczą raczej o braku odpowiedzi z Paryża. 10 czerwca 1921 roku zniecierpliwiony Peiper (zaczynając tym razem od „Drogi Panie”) dopytuje, czy jego poprzedni list dotarł i ośmiela się ponowić prośbę o odstąpienie mu zbędnych „druków o współczesnej literaturze i sztuce”... W kolejnym liście (z lutego 1922 roku) informuje o wydrukowaniu tłumaczeń wierszy Huidobry i prosi o potwierdzenie otrzymania listu („Błagam, niech Pan potwierdzi przesyłkę"20.) Możemy z dużą dozą prawdopodobieństwa zrekonstruować, co było przyczyną milczenia Chilijczyka. Rozwiązanie podsunął sam Peiper, kiedy w „Zwrotnicy” w listopadzie 1922 roku napomknął:

Pewien głośny poeta zagraniczny, przebywający stale w Paryżu i piszący po francusku, obraził się raz na mnie poważnie, kiedy styl jednego z jego cyklów poetyckich nazwałem nowoczesną formą symbolizmu ${ }^{21}$.

Nie znamy odpowiedzi Huidobry. Możemy jedynie się domyślać, które sformułowania Peipera mógł odebrać jako niefortunne. Są one niezwykle interesujące, ponieważ nie tylko pozwalają uzupełnić historię znajomości dwóch poetów, ale również umożliwiają rekonstrukcję pewnego etapu kształtowania się światopoglądu poetyckiego przyszłego twórcy „Zwrotnicy”. Choć już na wstępie swojej relacji z lektury wierszy Huidobry (La Torre Eiffel i Ecuatorial) deklaruje Peiper postawę antysentymentalną („Wyrafinowane metody, których używa Pan, by oczyścić produkt współczesnej mechaniki z gorączki wizji sentymentalnych, wydaje mi się jedynym sposobem robienia dzisiaj poezji"22.), w dalszym wywodzie odwołuje się wyraźnie do preawangardowej koncepcji liryzmu. Pisze między innymi:

Słowo „kreacjonizm” nie wydaje mi się obejmować tego, co esencjonalne w pańskiej poezji, a ponieważ nie chcę więzić jej w nowym -izmie, powiedziałbym, że elementem najbardziej charakterystycznym pańskiego procesu kreacyjnego wydaje mi się wizja - symbol tego, co wewnętrzne, wizja, która tłumaczy życie duszy. Dlatego, choć Pan unika „moi haissable” (szczególnie w swoich książkach pisanych w języku francuskim), to, co pańskie, kołacze spod pańskich najbardziej obiektywnych kreacji, słyszy się to ,ja” i nawet można określić ton, w jakim przemawia. Każdy z pańskich wierszy tłumaczy określony stan duszy. W każdym z pańskich wierszy jest jakaś dokładna jedność emocji.

20 Tamże, s. 165.

21 T. Peiper, Metafora teraźniejszości, „Zwrotnica” 1922, nr 3. Cytowane zdanie pochodzi z przypisu, który usunął Peiper, przygotowując wydanie Tędy w 1930 roku. Ta korekta uznana została za jeden z przejawów „zacierania śladów” przez pisarza.

22 Ten i następny cytat za: B. Lentas, Tadeusz Peiper $w$ Hiszpanii, s. 162. 
Również inne zwroty („tłumaczenie wewnętrznej rzeczywistości”, „Środki wizyjne [...], które powinny być symbolami korespondujących ze sobą uczuć”, „korelacja między stanami psychicznymi i wizjami, które je wyrażają”, „umiejętność sugestii”, „ewokacja uczuciowa”) podpowiadają z jednej strony, dlaczego ta interpretacja nie mogła przypaść Huidobrze do gustu, a z drugiej zdradzają, że w 1921 roku, a więc po powrocie z Hiszpanii, poglądy Peipera wciąż się kształtowały. Język, jakim się posłużył w liście do chilijskiego pisarza, świadczy o tym, że autor Nowych ust nie wrócił $\mathrm{z}$ dopracowanym programem poetyckim. Przeciwnie, dopiero szukał narzędzi (pojęć, terminów, metafor), którymi mógłby ująć swoją wizję poezji. Lekcja, jaką wyniósł z niefortunnego kontaktu z Huidobrą, była $\mathrm{z}$ pewnością ważnym doświadczeniem $\mathrm{w}$ tym procesie. $\mathrm{Z}$ tego punktu widzenia bezpodstawne wydają się zarówno głoszona przez Peipera w opublikowanym w 1930 roku Tędy opinia, że za granicę wyjeżdżał z ukształtowanym poglądem estetycznym, wymagającym jedynie utwierdzenia, jak i domniemywania komentatorów, że jego program był efektem przetransponowania na grunt polski awangardowych wynalazków, które miał szczęście poznać gdzie indziej23. Wygląda raczej na to, że jego znajomość koncepcji Huidobry była dość pobieżna i ograniczała się do podstawowej idei konotowanej przez termin „kreacjonizm”, tj. do koncepcji stwarzania w dziele realności czysto literackiej, niezależnej od jakiejkolwiek rzeczywistości zewnętrznej. W liście do Huidobry Peiper w istocie podejmuje próbę uzupełnienia tej wstępnej wiedzy i przypisuje twórcy kreacjonizmu pewne domniemane przez siebie intencje. Jest zresztą świadom ryzyka, jakie wiąże się z taką samodzielną interpretacją:

Kontynuować pierwsze wrażenia, które spowodowała lektura Pańskich wierszy? Obawiam się, że nadużywam Pańskiej cierpliwości. Zdaję sobie sprawę, że dużo z tego, co mówiłem, mogłoby być produktem chwili, błędu lub przynajmniej niedokończone. Lecz dlatego, że interesują mnie Pańskie opinie estetyczne (które przypuszczam Pan da wkrótce mi bliżej poznać), i dlatego, że chciałbym zachować czystość moich bezpośrednich wrażeń, sformułowałem je przed zapoznaniem się z Pańskim programem estetycznym. Bardzo

${ }^{23} \mathrm{O}$ uporczywości tego stereotypu świadczy np. wypowiedź Czesława Miłosza w rozmowie z Aleksandrem Fiutem (Czesława Miłosza autoportret przekorny, Kraków 1994, s. 323): „[...] pojęcie drugiej Awangardy jest sztuczne, używane w celach wyłącznie mnemotechnicznych, żeby w jakiś sposób zebrać w jedno osobowości najrozmaitszej proweniencji. Tak że lepiej nie używajmy terminu druga Awangarda. Nie było nic takiego. Powiedzmy - Ważyk. Ważyk reprezentował jakąś awangardę, ale dlaczego drugą? Ważyk ogłaszał wiersze w latach dwudziestych, kiedy powstała Awangarda Krakowska. On jednak reprezentował inną wersję, on wychodził od Apollinaire’a. Tamci? - Licho wie! Tamci wychodzili z poezji hiszpańskiej, którą Peiper przywiózł”. 
by mnie interesowało, co Pan myśli o moim sposobie widzenia Pańskiej poezji [podkreślenie moje - A.K.] ${ }^{24}$.

Na odpowiedź czekał Peiper ponad rok. Dwukrotnie się jej domagał i ponawiał prośbę o nadesłanie tekstów teoretycznych („czekam na Pańskie studia estetyczne"25). Tymczasem budował własną teorię poezji. $\mathrm{Z}$ pewnością wiele $\mathrm{z}$ jej elementów pochodziło z koncepcji, które poznał podczas nieobecności w kraju. Nie przejął ich jednak w mechaniczny sposób. Można odnieść wrażenie, że jego propozycja powstała głównie jako efekt swoistego bricolage'u, przemyślanej autorskiej syntezy rozmaitych idei, które wydały mu się interesujące. Podobnie jak artykuł Nowa poezja hiszpańska, tak i pierwszy list do Huidobry zawiera zapowiedzi kilku intrygujących Peipera spraw, które zyskają rozwinięcie w tekstach drukowanych w „Zwrotnicy”. Przede wszystkim zaprząta go kwestia, jak pogodzić autonomię obrazów poetyckich („kreacyjnie” odrealnionych) z - odczuwaną przez siebie jako nieusuwalny wymóg - potrzebą organicznej całości. Podobnie jak w artykule o poezji hiszpańskiej koncentruje uwagę na zdaniu:

Podstawowe zachowanie, które Panu służy, by osiągnąć cel, wydaje się zawierać w szczególnej koncepcji roli, którą powinno odgrywać zdanie poetyckie. Każde pańskie zdanie mówi to, co powinno powiedzieć, nie przez swoje znaczenie słowne, lecz przez swoją ewokację uczuciową, którą w nas wytwarza. Każde zdanie jest niezależne od swojego „obiektu”. Znaczy zawsze jedno ze skojarzeń, które budzi w naszej wrażliwości. Otrzymuje konkretne znaczenie dzięki swojej relacji z całością wiersza. Ta niezależność zdania w obliczu obiektu, w obliczu świata zewnętrznego, w obliczu warunków, które ujarzmiają rzeczywistość, konstytuuje najpotężniejszą jakość pańskiego języka. Cóż za obrazy! Cóż za wizje! Rzeczy, które wydają się najbardziej oddalone jedne od drugich, przytulają się i się łączą. Znikają dystanse, czas się redukuje do chwili lub do kilku chwil, ciężar dostaje skrzydeł. W ten sposób rodzi się nowy świat, w którym wszystko jest możliwe.

I znowu, jak w zalążku, dostrzegamy zapowiedź idei, które „rozkwitną" później: idea ekwiwalentu, idea pseudonimu, idea całościowej konstrukcji ogarniającej z pozoru nieprzystawalne elementy. W tej perspektywie łatwiej zrozumieć, dlaczego sięgnął Peiper w pierwszej części swojego listu po wczesnomodernistyczny, „symbolistyczny” język. „Symbol”, „dusza”, „uczucia”, „życie duszy”, „stan duszy”, „ton”, ,jedność emocji”, a wreszcie ,ja" - to wszystko potrzebne było Peiperowi jako gwarancja całości, tzn. mówiąc w języku współczesnego literaturoznawstwa

24 Tamże, s. 163.

25 Tamże, s. 165. 
- gwarancja podmiotowości. Autotelizm peiperowski, choć zakładał skrajną niereferencyjność języka budującego poszczególne „obrazy” poetyckie, nigdy nie wyrzekł się domyślnej obecności pomiotu. Dodajmy - podmiotu świadomego i ściśle kontrolującego stwarzane przez siebie odrealnione „równoważniki” fragmentów realności. Choć często jego poezję odbierano jako przejaw skrajnego intelektualizmu ${ }^{26}$, z czasem nauczono się dostrzegać jej emocjonalnośćc7. Peiper okazał się nie tylko bardziej zachowawczy niż Huidobro, ale i silniej związany z tradycyjną ideą liryzmu niż można byłoby przypuścić. Ta cecha szczególnie da o sobie znać $\mathrm{w}$ trakcie jego sporu z koncepcją, która narodziła się w połowie lat dwudziestych w środowisku „Almanachu Nowej Sztuki”.

Krótko mówiąc, na początkowy entuzjazm Peipera wobec osoby i dzieła Huidobry rzucił cień korespondencyjny epizod. Ujawnił z jednej strony pewną rozbieżność estetycznych perspektyw obu poetów ${ }^{28}$, z drugiej - musiał uświadomić Peiperowi dystans, z jakim, mimo wszystko, został przez Chilijczyka potraktowany. W ostatnim liście zdobył się na jeszcze jedną prośbę, „wierząc w charakter [ich] przyjaźni”29:

Bardzo bym chciał wejść we współpracę z jednym z wielkich dzienników południowoamerykańskich, żeby przesyłać im kroniki polityczne i literackie dotyczące Europy Wschodniej. Dzięki temu zarobiłbym pieniądze potrzebne do wydawania mojego czasopisma. Właśnie straciłem możliwość współpracy z „El Sol” (na skutek zmiany dyrekcji w gazecie). Została mi jedynie korespondencja dla „La Publicidad” z Barcelony. Czy istnieje więc jakakolwiek możliwość, żeby Pan, wykorzystując swoje znajomości, ułatwił mi wejście do jednego z dzienników z Po-

${ }^{26}$ A.O. [S. Napierski], Nowe poezje, „Czas” 28.03.1924; S. Kołaczkowski, Powieść - Liryka - Dramat. 1919-1930, [w:] W. Feldman, Wspótczesna literatura polska, wyd. 8. Okresem 1919-1930 uzupełnił S. Kołaczkowski, Kraków 1930, s. 664; J. Kott, Drogi awangardy poetyckiej w Polsce, „Przegląd Współczesny” 1935, t. 54, s. 401.

27 Zob. T. Kłak, Tadeusz Peiper i jego odbiorcy, „Pamiętnik Literacki” 1990, z. 4, s. 137.

${ }^{28}$ Zob. również M. Delaperrière, Huidobro et Peiper... Delaperrière zauważa „podobieństwo manifestów” i „różnice poetyk immanentnych”. Autorka wychodzi od obserwacji, że „Krytyka często zwracała uwagę na obeznanie Peipera z poezją hiszpańską i doszukiwała się w niej źródeł jego poetyki” (tamże, s. 272). Nie rozwija tej tezy, jedynie kilka zdań później stwierdza, że „Peiper z całą pewnością znał kolejne manifesty kreacjonistyczne (1914, 1916, 1918)" (tamże), nie podaje jednak źródła tego przekonania. Jednocześnie, komentując artykuł Nowa poezja hiszpańska, pisze: „Dziwić może fakt, że Peiper powiązał nazwisko Huidobro z ruchem ultraistycznym, podczas gdy od 1922 roku chilijski poeta wypracowywał estetykę «kreacjonistyczną», której reguły są bliskie estetyce autora Nowych ust" (tamże). Nie podejmuje jednak próby rozwikłania tych licznych niekonsekwencji, przechodząc do analiz manifestów i poetyk. Tymczasem nasuwa się wniosek, że w rzeczywistości „obeznanie” Peipera nie było tak pełne i konsekwentne, jak wielu krytyków skłonnych jest sądzić.

29 B. Lentas, Tadeusz Peiper w Hiszpanii, ten i następny cytat ze strony 166. 
łudniowej Ameryki? („La Prensa”, „La Nación de Buenos Aires” lub jakiś dziennik z Chile). Byłbym bardzo wdzięczny. Przepraszam, że zawracam Panu głowę sprawą, która z pewnością w ogóle Pana nie interesuje.

Nic nie wiemy o jego współpracy z czasopismami południowoamerykańskimi ani o tym, czy Huidobro próbował pomóc. Wiemy jedynie, że ich korespondencja nie nabrała, mimo nadziei polskiego pisarza, ożywienia i że pieniądze na wydawanie „Zwrotnicy” zarabiał Peiper głównie jako pracowity korespondent gazet hiszpańskich (dzięki ustaleniom badaczy wiemy, że w latach 1918-1924 ogłosił w tamtejszej prasie co najmniej 142 artykuły!30). Nietrudno z psychologicznego punktu widzenia zrozumieć, dlaczego po 1922 roku nazwisko Huidobry pada z ust Peipera coraz rzadziej ${ }^{31}$.

Drugim powodem pewnej ostrożności autora Tędy w ujawnianiu swoich hiszpańskich - i szerzej, europejskich - inspiracji mogła być obawa przed posądzeniem o intelektualny plagiat. Od pewnego czasu toczyła się w ówczesnym życiu umysłowym dyskusja o roli wpływów i zapożyczeń $^{32}$. Bezpośrednim powodem dysputy na początku lat dwudziestych była kontrowersja wokół ogłoszonych w latach 1918-1919 kilku tekstów naukowych na temat zależności polskiego romantyzmu od literatury europejskiej ${ }^{33}$. W efekcie „dyskusja nad tym zagadnieniem [tzw. literackich «źródeł», wpływów literackich, zapożyczeń i filiacji] [...] wyszła poza koło badaczy-specjalistów i stała się przedmiotem rozstrząsań felietonowych w tygodnikach i dziennikach" 34 . Autor tych słów - Wacław Borowy, wie-

30 Zob. tamże, s. 249; poza Lentas do ustalenia publikacji Peipera w Hiszpanii przyczynili się Gabriela Makowiecka, Ewa Pałka i Emilio Quintana, por. przypis 1. W prasie hiszpańskiej mogło ukazać się jeszcze więcej tekstów Peipera, niewykluczone, że niektóre publikowane były bez nazwiska autora.

31 Ostatni raz w szóstym numerze pierwszej serii „Zwrotnicy” w październiku 1923 roku.

32 Jeden z pierwszych głosów, usiłujących nadać jej głębszy charakter, należał do Wilhelma Feldmana, który trzeźwo zauważał (Pomniejszyciele olbrzymów. Szkice literacko-polemiczne, Warszawa 1907, s. 23-24): „Filologia pracująca grubymi narzędziami, czysto mechanistycznie segregująca słowa lub zdania na «oryginalne» lub znajdujące się u drugiego, poprzedzającego lub współczesnego autora, niemiecka ta, rzemieślnicza robota więcej szkody przynosi niż pożytku. Rzuca ona najfałszywsze światło na poetę, uważając go za świadomego lub bezwiednego złodzieja literackiego, pozostaje zawsze przy zewnętrznej jego szacie nie zaś przy tym, co jest formą, stylem w prawdziwie artystycznym znaczeniu wyrazu: jako indywidualny sposób chwytania, kojarzenia i przeżywania zjawisk".

33 J. Kleiner, „Pan Tadeusz” jako romans Walterscottowski, „Kurier Warszawski” 1916; S. Windakiewicz, Prolegomena do „Pana Tadeusza”, Kraków 1918; K. Wojciechowski, „Pan Tadeusz” Mickiewicza a romans Waltera Scotta, Kraków 1919.

${ }^{34}$ W. Borowy, O wplywach $i$ zależnościach $w$ literaturze, Kraków 1921, s. 1. 
dziony chęcią uporządkowania sporu - opublikował pod koniec 1920 roku cykl artykułów, które później weszły do książki $O$ wpływach $i$ zależnościach $w$ literaturze. Zanim to nastąpiło, w 1921 roku na łamach „Rzeczpospolitej” stoczył polemikę na temat „wpływologii” z Adamem Grzymałą-Siedleckim ${ }^{35}$. Już na początku 1922 roku ukazał się natomiast artykuł Plagiatowy charakter przełomów literackich $w$ Polsce $^{36}$ Karola Irzykowskiego, przedrukowany aż dwukrotnie w różnych miejscach ${ }^{37}$. Tym samym rozpoczęła się trwająca wiele miesięcy antyfuturystyczna kampania, której główną tezą była nieoryginalność polskiego futuryzmu. Publikacja Irzykowskiego zbiegła się z ogłoszeniem artykułu Nowa poezja hiszpańska i wywołała trwającą przez cały rok 1922 serię reakcji oskarżonych oraz kontrreakcji oskarżyciela ${ }^{38}$. Spór podsycił dodatkowo Stefan Żeromski, wydając Snobizm i postęp, gdzie również, choć zaledwie na kilku stronach, zarzucił futurystom naśladowanie obcych wzorów i zaprotestował wobec importowaniu rewolucji artystycznych. W takiej atmosferze w maju 1922 roku ukazał się pierwszy numer „Zwrotnicy”...

Pisał Irzykowski:

W czasie kiedy wskutek wypadków wojennych byliśmy odcięci od świata, ten i ów szczęśliwiec dostawał z Francji, z Włoch, zwłaszcza zaś z Rosji, parę numerów jakiegoś czasopisma futurystycznego, jakiś almanach ze zbiorem nowoczesnych utworów, rozpalał się nimi w tajemnicy i występował potem przed zdumioną publicznością w glorii oryginalności i męczeństwa, jaka jednak należy się tylko całej falandze, a nie jednostkom [podkreślenia tu i dalej autora]. Ogólnikowe pokwitowanie „wpływów” zagranicznych, przyznawanie się do któregoś z izmów, niewiele tu znaczy, jest tylko formalnością i odwracaniem uwagi. Ludzie, którzy sami z siebie nie byliby wpadli ani na dadaizm, ani na futuryzm, nie mają prawa do naśladownictwa i powinni być raczej tylko tłumaczami i wiernymi pośrednikami nowości zagranicznych. Mają oni wprawdzie mimowolną zasługę społeczną tzw. drugiej - i trzeciej ręki, jako pośrednicy,

35 A. Grzymała-Siedlecki, Mania ścisłości, „Rzeczpospolita” 1921, nr 19; tenże, Wptywologia, „Rzeczpospolita” 1921, nr 20; tenże, Jeszcze o wplywologii, „Rzeczpospolita” 1921, nr 21. Odpowiedzi Borowego: „Rzeczpospolita” 1921, numery: 25, 26, 30, 39, 53.

36 „Robotnik” 1922, nr 29 i 31 (styczeń).

37 „Kurier Lwowski” 1922, nr 25 i 31; „Naprzód” 1922, nr 26 i 28.

38 B. Jasieński, Kieszeń od kamizelki źódtem plagiatu. Rewelacyjne odkrycia p. Irzykowskiego, „Ilustrowany Kurier Codzienny” 1922, nr 37; K. Irzykowski, Kultura murzyńska $w$ Polsce, „Ilustrowany Kurier Codzienny” 1922, nr 37; A. Stern, Emeryt merytoryzmu (Z powodu ostatniego artykułu Irzykowskiego pt. „Plagiatowy charakter przełomów literackich $w$ Polsce”, czyli jeszcze o wiatrologii), „Skamander” 1922, nr 17; K. Irzykowski, Futurystyczny tapir (Przyczynek do sprawy zwyczajów literackich $i$ do sprawy plagiatu), „Ponowa” 1922, nr 5; K. Irzykowski, Na Giewoncie formizmu, „Przegląd Warszawski” $1922, \mathrm{nr} 6$. 
przez to są nawet w osobny sposób ciekawi, lecz to nie są pionierzy z krwi i kości ${ }^{39}$.

Peiper z pewnością musiał być świadkiem tej kampanii. Choć z czasem jako surowy krytyk futuryzmu awansował w oczach autora Likwidacji futuryzmu ${ }^{40}$ do roli chętnie przywoływanego sprzymierzeńca ${ }^{41}$, a w 1931 roku został nawet przez Irzykowskiego ostatecznie oczyszczony z podejrzeń o nieoryginalność ${ }^{42}$, przetaczające się po Polsce od 1922 roku gromkie pohukiwania na temat ,atmosfery pasożytnictwa, rozleniwienia umysłowego, w której żadna nowa myśl ani forma literacka zrodzić się nie może"43, nie mogły nie robić na przyszłym autorze $A$ wrażenia. Lęk przed zarzutem nieoryginalności był zresztą prawdopodobnie powszechną obawą, a podejrzewanie o plagiat - pospolitą obsesją. Choć po opublikowaniu zbiorów poetyckich głównie słyszał Peiper oskarżenia, że jego poezja jest niezrozumiała, nie ustrzegł się również posądzenia o wtórnośćc4. Carlos Marrodan Casas z pewną przesadą zauważa, że „znakomita większość [krytyków literackich] próbowała na wszystkie sposoby wykazać zależność Peipera od europejskich ruchów awangardowych"45, jednak z pominięciem wątku hiszpańskiego. I dodaje:

Trzeba przyznać, że sam Peiper „dopomógł” krytykom i historykom literatury zbagatelizować swój siedmioletni pobyt w a Hiszpanii nie przywiązując, na pozór, zbyt wielkiej wagi do tego okresu. Mogło to wynikać z dwóch przyczyn: albo

39 Plagiatowy charakter przełomów literackich w Polsce..., [przedr. w:] Stoń wśród porcelany. Studia nad nowsza myśla literacka w Polsce, Warszawa 1934. Cyt. za K. Irzykowski, Pisma, red. A. Lam, Stoń wśród porcelany. Lżejszy kaliber, Kraków 1976, s. $33-34$.

${ }^{40}$ K. Irzykowski, Likwidacja futuryzmu, „Wiadomości Literackie” 1924, nr 5; Irzykowski z aprobatą omawia Peipera krytykę futuryzmu, przeprowadzoną przez niego w ostatnim numerze „Zwrotnicy” pierwszej serii.

41 „Plagiatowy charakter przełomów literackich w Polsce musi Peiper w «Zwrotnicy» demaskować raz po razu” (K. Irzykowski, Burmistrz marzeń niezamieszkanych, „Wiadomości Literackie” z 4 stycznia 1931, [przedr. w:] Stoń wśród porcelany. Studia nad nowsza myślą literacka $w$ Polsce, Warszawa 1934. Cyt. za K. Irzykowski, Pisma, red. A. Lam, Stoń wśród porcelany..., s. 275).

42 „Tylko Peiper i Witkiewicz przemyśleli swoje eksperymentalne pozycje samodzielnie i oryginalnie, tak że wobec nich wpływologia nie czuje się sprowokowana" (tamże, s. 276).

43 Plagiatowy charakter przełomów literackich $w$ Polsce. Cyt. za K. Irzykowski, Pisma, red. A. Lam, Stoń wśród porcelany..., s. 36).

44 Wprost zarzut taki sformułował Adam Polewka (,Nowe usta”, „Gazeta Literacka” 1926, nr 1), pośrednio taka insynuacja wynikała z charakteru pytań zadanych Peiperowi przez Czuchnowskiego, zob. przypis 9.

45 C. Marrodan Casas, Tadeusz Peiper a ultraizm hiszpański, ten i następny cytat ze strony 3. 
rzeczywiście okres ten nie wywarł na Peiperze żadnego wpływu, albo w obawie przed zakusami i tak licznych „wpływologów” wolał redaktor „Zwrotnicy” usunąć w cień swój „epizod hiszpański”.

Druga przyczyna wydaje się prawdopodobniejsza.

Trudno zrozumieć, dlaczego krytyk zdecydował się na taką zawężoną interpretację. Końcowa alternatywa „nie było żadnego wpływu” lub „odebrać wpływologom pretekst do zarzutów” zestawia obok siebie w fałszywej dysjunkcji dwie niekoniecznie wykluczające się sprawy. Mógł przecież Peiper żywić przeświadczenie o samodzielności swojej myśli i jednocześnie podejrzewać, że inni będą odmiennego zdania (zwłaszcza w panującej wówczas atmosferze powszechnych podejrzeń). Casas ogranicza możliwe scenariusze do dwóch zaledwie wersji i w rezultacie narzuca odbiorcy swojego artykułu „logiczny” wniosek, że domniemana chęć Peipera, aby usunąć „epizod hiszpański” w cień, musiała wiązać się zarazem z jego świadomością takiego czy innego artystycznego długu. Niefortunny sposób referowania tej sprawy przez krytyka znajduje odzwierciedlenie również $\mathrm{w}$ zupełnie niepotrzebnym stosowaniu wobec niej skrajnych kwantyfikatorów („nie wywarł żadnego wpływu” i domyślnie „wywarł wielki/zasadniczy wpływ”), niewystarczających do opisu bardziej zniuansowanego, lepiej odpowiadającego delikatnej materii artystycznych i intelektualnych inspiracji.

Tekst Casasa - podobnie jak i opublikowany niedługo wcześniej, emocjonalny artykuł Andrzeja K. Waśkiewicza46 (wypowiedź ta zostanie skomentowana później) - przeanalizować można $\mathrm{w}$ istocie właśnie z punktu widzenia perswazyjnego celu autorów, zmierzających do przekonania czytającego, że „epizod hiszpański” Peipera skrywa (niejedną) tajemnicę („Sam pobyt, jak już i wspomnieliśmy, okryty jest tajemniczością"47; „W ten sposób zaczął się w życiu «ojca Awangardy» okres najbardziej tajemniczy"48). Za pomocą rozmaitych retorycznych zabiegów, aluzji, a niekiedy całkiem niepozornych chwytów, cel ten, jak dowodzą pisane później teksty, udało się osiągnąć.

Oto kilka przykładów. Kiedy pisze Casas, że „faktem bezspornym pozostaje jednak bagatelizowanie przez Peipera swego pobytu w Hiszpanii, ba, przemilczanie szczegółów tego pobytu"49, sugeruje, że w przypadku wcześniejszych (do Berlina i Paryża) i późniejszych podróży (do Wiednia) był Peiper wymowniejszy. Niestety, nic tego nie potwierdza; Peiper nale-

46 A.K. Waśkiewicz, Epizod hiszpański Tadeusza Peipera.

${ }^{47}$ C. Marrodan Casas, Tadeusz Peiper a ultraizm hiszpański, s. 3.

48 A.K. Waśkiewicz, Epizod hiszpański Tadeusza Peipera, s. 3.

49 C. Marrodan Casas, Tadeusz Peiper a ultraizm hiszpański, s. 3. 
żał w ogóle do osób powściągliwych („wstyd uczuć” nie był tylko programowym hasłem i nie dotyczył jedynie sfery twórczości) i nieskorych do publicznych zwierzeń, choć zdarzało mu się od czasu wtrącić jakąś bardziej osobistą informację ${ }^{50}$. Częściej jednak, paradoksalnie, skłonny był dzielić się rozmaitymi szczegółami na temat pobytu w Madrycie niż w Paryżu czy Berlinie ${ }^{51}$.

Inny przykład:

Wiadomości o pobycie Peipera w Hiszpanii można, na razie, uzyskać tylko z wypowiedzi samego pisarza. Są to wypowiedzi nader skąpe, jakby [podkreślenie tu i dalej moje - A.K.] próbujące zatrzeć ślady jego podróży. Oczywiście, niektóre ślady, gdyż Peiper wydrukował parę artykułów o tematyce hiszpańskiej. Pisał jednak nie o swoich rówieśnikach tworzących w łonie ruchu ultraistycznego, lecz o pisarzach generacji 98. Mamy więc peiperowskie artykuły o Blasco Ibanezie, M. de Unamuno, Pio Baroja, Manuelu Azana ${ }^{52}$. Jedynym śladem tego, że Peiper znał poezję ultraistów, jest artykuł $O$ nowej poezji hiszpańskiej53.

Fragment ten zawiera sugestię, że Peiper wiedział tyle samo na temat pisarzy pokolenia '98 oraz twórców młodszego pokolenia („rówieśników”, a więc, w domyśle, pisarzy łatwiej jakoby dających się poznać) i tylko tę ostatnią taił. Tymczasem przesiadujący w czytelni madryckiego klubu Ateneo przyszły papież polskiej awangardy miał zapewne w ciągu kilku lat wiele okazji, żeby poznać nieźle przede wszystkim starsze pokolenie literackie. Natomiast ruch ultraistyczny rodził się podczas tertulii, tj. nieoficjalnych spotkań młodzieży poetyckiej w Café Colonial. Peiper w tych zgromadzeniach nie uczestniczył (nie wspomina o tym ani on, ani żaden z ultraistów). Musiało minąć trochę czasu, zanim o nowej inicjaty-

50 Jak w wypowiedzi z 1928 roku z „Kuriera Porannego” (T. Peiper, Mam pani coś do powiedzenia, „Kurier Poranny” 1928, nr 174, s. 8): „Kiedy przyjechałem do Hiszpanii nie umiałem nawet kląć... Wiedziałem, że jestem w Pasajes, wiedziałem, że Francuzi nazywają tę miejscowość nadgraniczną Passage. [...] Wynająłem [pokój], mieszkałem [tam] 3 miesiące".

51 Por. choćby liczne uwagi w artykułach „Chłopi” w ttumaczeniu hiszpańskim („Nowa Reforma” 1921, nr 221) czy Azaña („Tygodnik Artystów” 1934, nr 3). Wiadomo również, że chętnie rozmawiał o Hiszpanii ze znajomymi (zob. W. Kragen, Wspomnienie o Tadeuszu Peiperze, „Nadodrze” 1971-1972, nr 26, s. 10: „O Hiszpanii opowiadał nieskończenie, zawsze barwnie, zawsze oryginalnie. Nagadawszy się, szedł do kuchni i własnoręcznie przyrządzał wspaniałe smakołyki hiszpańskie”), a publicznie nazwał siebie nawet hispanofilem (zob. Jeszcze jedna rewizja, „Czas” 1934, nr 94, [przedr. w:] T. Peiper, O wszystkim i jeszcze o czymś..., s. 325).

52 Notabene polityczny kontekst tych artykułów wskazuje, że jeśli można mówić o wykraczającej poza przeciętny poziom orientacji Peipera w tematyce hiszpańskiej, dotyczyła ona przede wszystkim sfery społecznej, a dopiero w drugiej kolejności artystycznej.

53 C. Marrodan Casas, Tadeusz Peiper a ultraizm hiszpański, s. 3. 
wie dowiedzieli się inni. To prawda, że przyjazd Huidobry do Madrytu w lipcu 1918 roku stanowił, jak wiemy z licznych późniejszych omówień ${ }^{54}$, niezwykły impuls dla młodych poetów. Jednak - i przyznaje to sam Casas - nie oznaczało to natychmiastowego wyklarowania się jakiejś czytelnej i powszechnie rozpoznawalnej linii estetycznej. Przeciwnie, w pewnym stopniu miała tę intencję oddawać sama nazwa - jedynym pewnikiem był deklarowany radykalizm artystyczny oznaczający chęć czerpania ze wszelkich awangardowych zdobyczy, o których młodzi poeci właśnie się dowiadywali. W czasie, kiedy Peiper był w Hiszpanii, robili przede wszystkim, prawem każdej nowości, dużo szumu. Pierwszy manifest opublikowali na początku 1919 roku. Nie można zapominać, że gdy Peiper szykował się do opuszczenia Hiszpanii, ultraizm dopiero nabierał rozpędu - poeci z zapałem publikowali kolejne manifesty i otworzyli w Sewilli pismo „Grecia”. Kolejne („Ultra”, „Alfar”, „Horizonte”) zaczęły się ukazywać w 1921 roku, po powrocie Peipera do Polski... Na jego publikację należy więc spojrzeć inaczej: jak na odważną interpretację zjawiska, które dopiero się kształtuje i o którym wie się co nieco, ale wciąż nie dość wiele („co Pan myśli o ultraizmie?” zapytywał Huidobrę w kwietniu 1921 roku, a więc już po przybyciu do Polski) oraz - nieskrywaną przecież wcale po latach - próbę przedstawienia przy tej okazji własnych poglądów. Wysiłki Peipera, aby nadać ultraistycznemu ruchowi jakąś bardziej uchwytną wykładnię, szły równolegle $\mathrm{z}$ dążeniem Jorge’a Louisa Borgesa. Za kwintesencje programu ultraistycznego uznawane są cztery punkty ${ }^{55}$, które ten pisarz sformułował dopiero w grudniu 1921 roku i opublikował w argentyńskim piśmie „Nosotros”, kiedy Peiper był już w kraju.

W innym miejscu cytuje Casas fragment omówienia Kazimierza Czachowskiego z III tomu Obrazu wspótczesnej literatury polskiej 1884-1934:

54 R. Cansinos-Assens, Un gran poeta chileno: Vicente Huidobro y el creacionismo, „Cosmópolis” 1.01.1919; C.G. Ruano, Vicente Huidobro, [w:] tenże, Veintidós retratos de escritores hispanoamericanos, Madrid 1952.

55 J.L. Borges, Ultraísmo, „Nosotros” 1921, vol. 39, nr 151, s. 468: „1. Reducción de la lirica a su elemento primordial: la metáfora; 2. Tachadura de las frases medianeras, los nexos, y los adjetivos inútiles; 3. Abolición de los trabajos ornamentales, el confesionalismo, la circunstanciación, las prédicas y la nebulosidad rebuscada.; 4. Sintesis de dos o mas imágenes en una, que ensancha de ese modo su facultad de sugerencia [(1) zredukowanie liryki do jej pierwotnego elementu, metafory; 2) wyeliminowanie zdań wtrąconych, spójnikowych, niepotrzebnych przymiotników; 3) unikanie ornamentów, wyznań, mówienia o okolicznościach, dydaktyki i wyszukanej niejasności; 4) synteza dwu lub więcej obrazów w jeden, by zwiększyć jego sugestywność)]. Cyt. za M.V. Utrera Torremocha, Estructura y Teoría del Verso Libre, Consejo Superior de Investigaciones Científicas (CSIC), Madrid 2010, s. 100. 
Zaznaczyć [...] warto, że zagraniczne doświadczenia Peipera nie ograniczyły się do utartych dróg niemieckich, francuskich i włoskich, bo - jak świadczą jego artykuły i przekłady poetyckie - poznał on gruntownie także środowisko młodej literatury hiszpańskiej.

\section{Komentarz Casasa:}

Skąd Czachowski wiedział o „bezpośrednim zbliżeniu” Peipera z wangardzistami zachodnioeuropejskimi i jego gruntownej znajomości środowiska ultraistów? Jeśli opierał się tylko na tłumaczeniach autora $T e ̨ d y$, to były oczywiście wiadomości nieco „na wyrost”.

Komentator nie dopowiada drugiej możliwości (może jednak wiedziat skadinad $i$ byly to wiadomości wiarygodne?), zostawiając to zadanie czytelnikowi. Następnie przywołuje cytowany już fragment z Tędy, w którym Peiper zaprzecza osobistej znajomości twórców omawianej przez siebie najmłodszej poezji hiszpańskiej. Krytykowi daje to asumpt do przypomnienia innej wypowiedzi (pochodzącej z również już przywoływanego wywiadu Mariana Czuchnowskiego ${ }^{56}$ ), w której Peiper stwierdza, że nie poznał żadnego z „tamtejszych” (tj. europejskich) awangardzistów, a zagranicznych współpracowników „Zwrotnicy” pozyskał dzięki malarzowi Moïse Kislingowi. Jednocześnie wskazuje Casas na różnicę między pierwotną wersją artykułu Kamedułom sztuki z 1924 roku a tą, jaka weszła do książki w 1930. Krytyk nie ma wątpliwości: usunięcie w tej ostatniej zdania o spotkaniu w Paryżu u malarza kubisty Louisa Marcoussisa dowodzi, że po udzielonym rok wcześniej (w 1929 roku) wywiadzie, „w którym o znajomości z Marcoussisem nie wspomniał, ba, nawet zaprzeczył, jedynym wyjściem dla Peipera było zatarcie śladów jakichkolwiek podobnych kontaktów" ${ }^{\prime 2}$. Nie bierze pod uwagę, że pytany o awangardzistów zagranicznych mógł Peiper nie pomyśleć o Ludwiku Kazimierzu Władysławie Markusie, który, podobnie jak Kisling, był dla niego krajanem z Polski. Sposób zestawienia kolejnych wypowiedzi sugerować ma, że twórca „Zwrotnicy” dążył do konsekwentnego „zatarcia śladów” dowodzących jego kontaktów z twórcami europejskimi. Tymczasem te wypowiedzi dotyczą różnych spraw i różnych kategorii logicznych. Czym innym jest informacja dotycząca znajomości młodych hiszpańskich ultraistów, a czym innym „awangardzistów zagranicznych”, czym innym w końcu znajomość z malarzem kubistą polskiego pochodzenia... Jednak krytyk bez wahania zestawia wszystkie te dane obok siebie, sugerując ich współmierność i traktując jako argument w jednej sprawie - rzekomej chęci ukrycia przez pisarza stanu rzeczywistego (Peiper dobrze poznat europejskie środowisko awangardowe), a w domyśle - zatuszowania dal-

56 Zob. przypis 9.

${ }^{57}$ C. Marrodan Casas, Tadeusz Peiper a ultraizm hiszpański, s. 3. 
szych ewentualnych „spraw wstydliwych” („Sprawa pobytu w Hiszpanii wydaje się być dla Peipera również sprawą wstydliwą"58.). Jakich - czytelnik znowu musi sam sobie dopowiedzieć, nie licząc, że zrobi to krytyk. $\mathrm{W}$ zamian przywołuje Casas jeszcze inny fragment $\mathrm{z}$ wielokrotnie cytowanego wywiadu - odpowiedź Peipera na pytanie Czuchnowskiego o związek „Zwrotnicy” z ruchem awangard zagranicznych:

Niemcy wpłynęły na powstanie „Zwrotnicy” przez uratowanie życia jej redaktorowi. Z futuryzmem włoskim łączyło „Zwrotnicę” potwierdzenie nowoczesności, które jednak nie pochodziło z Włoch, lecz z polskiego pozytywizmu; w ujmowaniu nowoczesności i w środkach artystycznych istniały między futuryzmem włoskim a „Zwrotnicą” jedynie różnice. Najnowsza poezja francuska dała nam wiele bodźców, lecz zupełnie wyraźnie przeciwstawialiśmy się jej uległości wobec swobody wyobraźni, jej oddalaniu się od postulatu budowy artystycznej [podkr. moje - A.K.]. Z młodą Hiszpanią mamy tyle wspólnego, ile mieć muszą synowie tej samej epoki, a może należałoby zaznaczyć pewne wpływy, jakie wywarły na tamtejsze orientacje moje artykuły, poufnie tłumaczone przez polskich malarzy osiadłych w Madrycie, a nawet notowane w tamtejszych pismach ${ }^{59}$.

Pozostawia jednak bez komentarza większość poruszonych przez Peipera wątków, koncentrując uwagę jedynie na ostatnim. Kwestionuje prawdopodobieństwo wpływu Peipera na ultraistów „ze względów chronologicznych”60 i zauważa, że „ciągle podkreślany brak kontaktów z awangardzistami hiszpańskimi ma swoje uzasadnienie chyba $\mathrm{w}$ obawach przed oskarżeniami o korzystanie $\mathrm{z}$ cudzych zdobyczy". Trudno nie zauważyć, że podobny wniosek kłóci się z innym - nieskomentowanym - fragmentem tej wypowiedzi, kiedy Peiper otwarcie wskazuje na inspiracje płynące $z$ poezji francuskiej, choć zarazem podkreśla, że nie przyjmował ich bezkrytycznie. Można odnieść wrażenie, że w chęci przekonania do dwóch głównych tez artykułu (o głębokich związkach hiszpańskiego ultraizmu i twórcy „Zwrotnicy” oraz jego rzekomej chęci ukrycia tej towarzyskiej zażyłości z jednej, a twórczej zależności z drugiej strony) Casas w różny sposób używa wiadomości na temat relacji Peipera z europejską, a głównie paryską, awangardą; jeśli jest mu to na rękę, wykorzystuje informacje o domniemanym tuszowaniu przez pisarza tych związków jako przejawu jego ogólniejszej skłonności, jeśli zaś Peiper je ujawnia, krytyk tego nie dostrzega...

58 Tamże.

${ }^{59}$ Cyt. za T. Peiper, O wszystkim i jeszcze o czymś..., s. 188.

${ }^{60}$ C. Marrodan Casas, Tadeusz Peiper a ultraizm hiszpański, ten i następny cytat ze strony 3 . 
Analizę tekstu Casasa można by kontynuować, wydobywając kolejne niekonsekwencje i pokazując, jak, dzięki aluzjom, niedopowiedzeniom i retorycznym chwytom, budowana jest specyficzna perswazja. Nieco inaczej skonstruowany jest artykuł Waśkiewicza ${ }^{61}$. W pełnym emocji wywodzie kilkakrotnie powtarza autor przeświadczenie, że w „epizodzie hiszpańskim” kryje się odpowiedź o narodziny Peipera poety, „tam jest początek..." stwierdza. Kilkakrotnie też apeluje o podjęcie studiów na ten temat. Tekst Casasa odczytywać można jako odpowiedź na to wezwanie. Obaj autorzy identycznie argumentują, dlaczego należy doszukiwać się celowego zatajenia przez Peipera szczegółów pobytu w Madrycie - głównie wskazując „niekonsekwencje” pisarza. Tekst Casasa zawiera jednak zdecydowanie więcej informacji oraz fragmentów analizy tekstów, podczas gdy artykuł Waśkiewicza, wyraźnie nawiązujący do niedawnej śmierci twórcy „Zwrotnicy” - Peiper umarł w 1969 roku, artykuł ukazał się w 1971 - zmierza do podkreślenia całokształtu jego zasług dla poezji polskiej. Pewien istotny szczegół różni jednak tekst Waśkiewicza: motyw zaginionej walizki. Sposób, w jaki krytyk przywołał tę historię, sprawił, że została wchłonięta przez narrację o zatajanym przez poetę hiszpańskim początku i jednocześnie opatrzona raz na zawsze znakiem zapytania: „Teza o kradzieży jest niemożliwa do obalenia. Także - nie da się bezspornie udowodnić"62. Tym samym ostatecznie ugruntował krytyk topos, który pełną realizację zyskał w niedawno opublikowanej książce Beaty Lentas ${ }^{63}$.

Tadeusz Peiper $w$ Hiszpanii to efekt niezwykłej pracy. Autorka dotarła do wielu dokumentów, odsłaniających nieznane karty działalności pisarza. Przede wszystkim ustaliła okoliczności współpracy Peipera z prasą hiszpańską już po przyjeździe do Polski i znacznie poszerzyła listę jego hiszpańskojęzycznych publikacji. Dotychczasowa, sporządzona przez Jaworskiego, kończyła się na roku 1921. Lentas nie tylko uzupełniła ją o kilkadziesiąt (!) nowych pozycji, ale również odkryła, że korespondencje do Madrytu wysyłał Peiper z kraju jeszcze w 1924 roku (a nawet pojedyncze w 1926 i 1929).

W swoje ustalenia wplotła imponująco wiele szczegółowych informacji pozwalających zrekonstruować obraz życia umysłowego hiszpańskiej inteligencji i międzynarodowej bohemy przebywającej podczas pierwszej wojny światowej w Madrycie. Zwłaszcza wiele zrobiła autorka, aby przybliżyć okoliczności życia polonii artystycznej, w zapale archiwistycznym wikłając się niekiedy w rozważania, które niewiele z jej głównym bohate-

${ }^{61}$ A.K. Waśkiewicz, Epizod hiszpański Tadeusza Peipera...

62 Tamże, s. 3.

${ }^{63}$ B. Lentas, Tadeusz Peiper w Hiszpanii. 
rem mają wspólnego ${ }^{64} \ldots$ Jednak starania Lentas nie są prostym i pełnym poświęcenia dążeniem do zarysowania tła pobytu Peipera w Madrycie. Autorka zmierza przede wszystkim do zebrania możliwie dużej liczby argumentów na rzecz tezy - nie nowej, a jedynie forsowanej w skali dotąd niepraktykowanej - o rozmyślnym zatajaniu przez autora Tędy okoliczności „hiszpańskiego epizodu”. W tym celu Lentas przywołuje formułę Waśkiewicza, który określił pewne zachowanie Peipera jako „chwyt «stratega»"65. Podejmując główną intencję artykułu Waśkiewicza, osobliwie interpretuje jednak badaczka cytowaną formułę; krytyk posłużył się nią w nieco innej funkcji66. Lentas używa jej dla zobrazowania - przyjętej jako niepodlegający dyskusji, arbitralnie założony punkt wyjścia - celowej „operacji tworzenia własnej biografii” [L 8]67 przez Peipera. Już w pierwszych akapitach autorka aktualizuje wszystkie elementy hiszpańskiego toposu. „Nie są znane początki jego twórczości”, „poeta niechętnie ujawniał informacje dotyczące niemal sześciu lat [...] spędzonych w Hiszpanii”, „nie wiadomo, z kim artysta się spotykał w Madrycie, w jakich środowiskach przebywał i co naprawdę łączyło go z hiszpańską awangardą”, „przyszły twórca awangardy znika [...] na dobre kilka lat”, „jakby zapada się pod ziemię", „autor Tędy po powrocie do kraju był małomówny i wyraźnie powściągliwy w wypowiedziach dotyczących pobytu za granicą" [L 8] - to wszystko czytamy już na pierwszej stronie! Charakterystyczna hiperbolizacja (,brak jakichkolwiek pewnych informacji o tamtym okresie” [L 9]) i retoryczna emfaza („Dlaczego i co chciał ukryć Tadeusz Peiper?” [L 9]) nie opuszczają stylu autorki w całej książce.

Gorliwość dociekań archiwalnych nie idzie niestety w parze z bezstronnością i gotowością do falsyfikacji przyjętej na wstępie tezy. Przeciwnie, od początku dopuszcza się autorka nieścisłości. W pierwszym rozdziale powołuje się na Stanisława Jaworskiego i przypisuje mu opinię, że pobyt na Półwyspie Iberyjskim to „najbardziej niejasny” okres w życiu Peipera. Tymczasem edytor jego Pism w nocie biograficznej odnosił się raczej do wcześniejszego czasu - lat studiów w Berlinie („O przebiegu studiów nic nie wiadomo, jeśli nie brać pod uwagę losów Juliusza Ewskiego z powieści Ma lat 22"68) i okoliczności wyjazdu do Paryża. Na tle tych skąpych danych „epizod hiszpański” wydaje się wręcz świetnie

${ }^{64}$ Zob. rozważania porównujące działalność pracowni sztuki dekoracyjnej Jahlów i podobnej Delaunayów [L 239].

${ }^{65}$ Lentas posługuje się tym określeniem kilkakrotnie, por. B. Lentas, Tadeusz Peiper $w$ Hiszpanii, s. 8, 24 (tu niedokładnie jako „odruch stratega”), 25.

66 Jako dowód na lekceważący stosunek Peipera korespondenta do powinności „informacyjnej rzetelności”.

67 W ten sposób lokalizuję dalsze cytaty z książki Tadeusz Peiper w Hiszpanii.

68 S. Jaworski, Nota biograficzna, [w:] T. Peiper, Tędy. Nowe usta, s. 419. 
rozpoznany, także dzięki Peiperowi; Jaworski ujawnia dodatkowo, że „[w]ielu cennych wiadomości o okresie hiszpańskim udzielił [mu] p. Wacław Zawadowski" 69 .

Podobnej nierzetelności, a wręcz manipulacji dopatrzeć się można $\mathrm{w}$ użyciu przez Lentas innej alegacji. W przypisie do sformułowania o „chwycie stratega”, stosowanym rzekomo permanentnie przez Peipera, obok Waśkiewicza umieszcza autorka Tadeusza Kłaka oraz jego rozprawę Peiper $i$ jego odbiorcy. Jak komentuje, „badacz ukazuje twórcę $A$ jako autora, który potrafił stworzyć wokół siebie prawdziwą kampanię literacką o charakterze reklamowym" [L 233]. Tymczasem Kłak pokazuje ${ }^{70}$, że do podobnej świadomości Peiper dojrzewał powoli i że na początku, ograniczając się do tworzenia „poezji dla dwunastu”, wierzył raczej $\mathrm{w}$ inne metody pozyskiwania nowych czytelników - przede wszystkim przez jak najbardziej dogłębne, w swoim rozumieniu, tłumaczenie teoretycznych podstaw swojej poezji. Temu służyła „Zwrotnica” i drukowane w niej artykuły. Dopiero brak oczekiwanego odzewu na pierwsze dwa zbiory poetyckie skłonił Peipera do przygotowania bardziej systematycznej akcji, której owocem była publikacja Nowe usta, a wcześniej cykl odczytów w pierwszych miesiącach 1925 roku. Jednak w ujęciu autorki książki Tadeusz Peiper $w$ Hiszpanii poeta jawi się jako wykalkulowany strateg, który precyzyjnie planował wszystkie posunięcia, mając tylko jeden cel - ukryć swoje hiszpańskie filiacje. Badaczka uważa nawet, że niejasna data powrotu Peipera do Polski (kontrowersja dotyczy tego, czy było to pod koniec 1920 roku, czy na początku 1921) służy temu celowi: „Jeśli zaś mało precyzyjnie określił datę powrotu, to gest ten należałoby odczytać jako «odruch stratega»" [L 24]. Lentas konsekwentnie podporządkowuje swojej nadrzędnej tezie każdą niejasność: dlaczego nie wrócił w 1918? - nie dlatego, jak twierdzi, że brakowało mu pieniędzy. Autorka ustala, ile mógł zarabiać i nie przyjmuje argumentu pisarza. Dopuszcza inny, że czekał na niezbędne dokumenty. Ale nie waha się sformułować również „oczywistego” przypuszczenia:

Choć może powodem, dla którego przedłuża on swój pobyt, jest nowy ruch w sztuce hiszpańskiej - ultraizm? [...] prawdopodobnie to raczej pokusa obcowania tego, co się działo w ówczesnym Madrycie, nie zaś względy finansowe, skłoniła [go] [...] do wydłużenia hiszpańskiej przygody" [L 22-23].

Chciałoby się zapytać: dlaczego w takim razie wrócił? Przecież opuścił Hiszpanię w momencie, kiedy ultraizm dopiero się formował, w samym środku tego procesu...

69 Tamże, s. 418; notabene z listów Zawadowskiego do Jaworskiego korzysta również Lentas i zamieszcza ich faksymile w jednym z aneksów.

70 T. Kłak, Tadeusz Peiper i jego odbiorcy, s. 119-123. 
Lentas nie powstrzymuje się również od retorycznych zabiegów, których celem jest zasugerowanie niezwykle aktywnego uczestnictwa Peipera w ruchu ultraistycznym już po powrocie do Polski. Wprowadzając $\mathrm{w}$ pierwszym rozdziale $\mathrm{w}$ zagadnienie publicystycznej działalności Peipera w Hiszpanii (dalej poświęca tej współpracy osobny rozdział), wspomina, że od 1920 roku regularnie zaczyna drukować w dzienniku „La Publicidad” i dodaje: „W kolejnych latach pisze również do «Ultra» $\mathrm{i}$ «Alfar» dwóch czołowych organów hiszpańskiej awangardy" [L 20]. Sugestia jest jasna: zestawienie tych dwóch form współpracy wskazuje, że istnieje podstawa takiego zestawiania; tymczasem w „La Publicidad” ukazuje się kilkadziesiąt tekstów Peipera, natomiast w „Ultrze” jeden, w listopadzie 1921 roku, na temat książki Leona Chwistka Wielość rzeczywistości, a w „Alfarze” - dwa, w 1926 i 1929 roku (pierwszy to właściwie tekst polemizujący z książką Guillerma de Torre Literatura europeas de la vanguardia; drugi jest komentarzem Peipera do niewielkiego wyboru wierszy polskich poetów).

$\mathrm{Z}$ równą skrupulatnością, w której pieczołowite dociekanie źródeł splata się z konsekwentnym umacnianiem raz powziętej tezy, omawia autorka książki Tadeusz Peiper w Hiszpanii sprawę „hiszpańskiej” brody Peipera (w podrozdziale Walka o brodę) oraz jego zaginionej walizki (na jedenastu stronach!). Co do brody - uznaje Lentas pod ciężarem argumentów jej oryginalność i suwerenność, ale i tak widzi w niej przejaw „duchowego powinowactwa z kulturą zapirenejską”, „związku, który później ten strateg starał się ukryć" [L 25] i dlatego... zgolił brodę pod koniec lat dwudziestych [L 38]! (dlaczego wobec tego, jakże nieuważnie!, w 1934 roku znowu nazwał siebie „hispanofilem”?). Co do walizki - „do tej pory unoszą się [nad nią] opary tajemnicy" [L 28]. Tajemniczość - ważny składnik hiszpańskiego toposu - bez wahania przeobraża jednak Lentas w interpretacyjną korzyść, konstruując tezę, że motyw ukradzionej (naprawdę lub nie) walizki z niepublikowanymi rękopisami wierszy, pozwolił Peiperowi stworzyć autolegendę, której stawkę już znamy: „[...] koncentrując uwagę odbiorcy i kolegów literatów na "zaginionym początku», chciał zakryć swoje hiszpańskie lata, czyli inaczej hiszpański początek" [L 37] oraz „wstydliwy dla siebie fakt, że nie sam siebie ustanowił” [L 39]. Krytyczka wykorzystuje każdą okazję, aby przedstawić autora Żywych linii jako „konstruktora własnej biografii” [L 39]. Nie stara się jednak odnieść swoich odczytań do interpretacji innych. Tymczasem sprawa zaginionej walizki - tak bardzo przez Peipera przeżywana i tak często wspominana - w opinii wielu ${ }^{71}$ mogła mieć swój udział w późniejszym

${ }^{71}$ K. Karasek, Nota biograficzna, [w:] tenże, Poezje wybrane, Warszawa 1978; A. Gronczewski, Droga do Czarnego, „Miesięcznik Literacki” 1987, nr 5. 
rozwoju choroby umysłowej pisarza. Lentas, uparcie obsadzająca Peipera w roli chłodnego kalkulatora, precyzyjnie budującego swój publiczny wizerunek, nie próbuje tych okoliczności w jakikolwiek sposób uzgodnić. W ogóle, przyznać trzeba, traktuje swojego bohatera dość bezdusznie i tendencyjnie, jak śledczy przekonany o winie podejrzanego.

$\mathrm{W}$ pełni potwierdza to podejście drugi rozdział, który rozwijając koncept skradzionego/ukrytego początku, zatytułowała Lentas jako Odzyskany poczatek. Peiper jako hiszpański publicysta. W tej części książki referuje autorka przebieg i charakter współpracy pisarza $\mathrm{z}$ prasą hiszpańską. Odkrywa Peipera jako znawcę spraw politycznych, który z czasem potrafił wyrobic sobie status korespondenta specjalisty prowadzącego stałą rubrykę na temat sytuacji Europy Środkowo-Wschodniej. Badaczka kompetentnie rekonstruuje również kontekst działalności dziennikarskiej Peipera, opisując szczegółowo sytuację prasy hiszpańskiej na początku XX wieku. Drobiazgowe badania autorki przechodzą jednak stopniowo w inny rodzaj dyskursu, a mówiąc dokładniej - powracają do zarzuconej narracji, w której centralną figurą jest Peiper strateg. Konsekwentnie „strategiami” nazywa Lentas trzy wyodrębnione przez siebie, dominujące w analizowanej publicystyce postawy (I. Eksponować polski punkt widzenia; II. Upowszechniać antybolszewickie stanowisko; III. Manifestować sympatie lewicowe, demokratyczne i liberalne). Jej uwagę przykuwają relacje $\mathrm{z}$ wydarzeń wojny polsko-bolszewickiej, a przede wszystkim „kwestia źródeł” [L 78], z jakich czerpał informacje. Autorka dowodzi, że przebywając w 1920 roku (a więc w ostatniej fazie wojny) w Wiedniu, posiłkował się Peiper prasą zagraniczną i polską oraz wiadomościami przekazywanymi od lepiej poinformowanych osób, bezpośrednich świadków, dyplomatów. Wielu z tych informatorów występuje w artykułach Peipera anonimowo. Choć nie ma w jego poczynaniach niczego odbiegającego od zwyczajnych praktyk dziennikarskich, tym bardziej zrozumiałych $\mathrm{w}$ sytuacji, kiedy informuje się o wydarzeniach wojennych ${ }^{72}$,

72 Peiperowi zależało bardzo na przekazaniu odbiorcy hiszpańskiemu nie tylko informacji o przebiegu walk, ale również o uświadomieniu mu wagi zagrożenia, jakie niósł ze sobą bolszewizm. Można zakładać, że Peiper, pozbawiony złudzeń co do wartości tej ideologii, gotów był akceptować i stosować wszelkie metody, dzięki którym mógł upowszechniać antysowieckie przesłanie.

Warto przy tej okazji skomentować sposób, w jaki Lentas referuje „postawę dziennikarską” Peipera podczas II wojny światowej: „W obliczu [hiszpańskich] artykułów Peipera o Rosji sowieckiej - ich demaskatorskiego charakteru - warto, byśmy pamiętali, że później, w latach czterdziestych, gdy trwała jeszcze II wojna światowa, jego postawa dziennikarska uległa przeobrażeniu. Tytuły publikacji w piśmie Związku Patriotów Polskich «Wolna Polska» - jak napisał Jaworski - mówią same za siebie [S. Jaworski, Wstęp, [w:] T. Peiper, Pisma wybrane, Wrocław 1979, s. VI]. Rzeczywiście, We wspólny bój, Sąsiad, sojusznik, przyjaciel przywodzą na myśl wzorcową sowiecką propagandę. Dlaczego publicysta, który 
Lentas wykorzystuje okazję, aby sformułować podejrzenie, że „oprócz prawdziwych informatorów niekiedy stwarzał on świadków fikcyjnych po to, by uprawdopodobnić swoje korespondencje" [L 79].

Kolejny krok autorki to wydobycie zbieżności między artykułami Peipera a publikacjami ukazującymi się w tym czasie w polskiej prasie. Lentas wskazuje trzy takie przypadki ${ }^{73}$. Omawia je szczegółowo i formułuje na tej podstawie uogólniający sąd, że „«zapożyczenia» z cudzych tekstów zdarzały się Peiperowi na różnych poziomach konstruowania własnych”. I dodaje: „Wpływy te możemy nazwać tematycznymi, stylistycznymi oraz frazeologicznymi” [L 90]. Nie waha się stwierdzić „wtórność, żeby nie powiedzieć: plagiatowość prac twórcy Żywych linii” [L 90]. Te mocne oceny nie znajdują jednak potwierdzenia. Jak można się przekonać podczas lektury zestawionych przez Lentas w osobnym aneksie fragmentów inkryminowanych artykułów Peipera i fragmentów publikacji innych autorów, nie ma podstaw, aby mówić w tym przypadku o plagiacie. $\mathrm{Z}$ pewnością ma natomiast rację autorka, kiedy dostrzega podobieństwa: Peiper wykorzystał elementy cudzych wypowiedzi i włączył je do swoich tekstów, napisanych jednak od początku własnymi słowami.

z pełną świadomością analizował na łamach prasy hiszpańskiej reżim sowiecki, w nowych okolicznościach nawoływał do «współpracy, współwalki, współbogu» z tą samą władzą sowiecką? Dlaczego pisał o potencjalnych korzyściach z przyjęcia w Polsce ustroju bolszewickiego? Dlaczego sprawę katyńską przedstawiał jako jeden z tematów antysowieckiej propagandy niemieckiej i rządu Sikorskiego? Trudno tu cokolwiek jednoznacznie stwierdzić i tym samym wydać wyrok na Peipera publicystę. Czy kierowały nim strach przed Niemcami i nienawiść do nich, ponieważ umieścili jego pisma na indeksie ksiąg zakazanych i ścigali go ze względu na jego żydowskie pochodzenie? Czy może strach przed Sowietami? Zapewne jedno i drugie. Raczej mało prawdopodobna bowiem byłaby hipoteza, że w bezpośrednim kontakcie - w głębi Rosji - doznał Peiper prawdziwego nawrócenia na wiarę bolszewicką, jak wielu artystów w tamtym czasie” [L 89]. Po raz kolejny razi deficyt empatii badaczki. Dla każdego, kto zapoznał się z tragiczną historią Peipera, znaną choćby dzięki materiałom zgromadzonym w tomie Maski (Tadeusz Peiper, [w:] Maski. Transgresje 4, wybór, opracowanie, redakcja M. Janion, S. Rosiek, t. l, Gdańsk 1986), stawianie podobnych pytań musi się wydać czymś niestosownym; to oczywiste, że rzekomy akces do bolszewizmu i wynikająca stąd „postawa dziennikarska” musiały wynikać z ostatecznego załamania tego człowieka; nie tyle o „postawie dziennikarskiej” należy tu mówić, ile o „postawie egzystencjalnej”. Chłodne rozważanie przyczyn ewentualnego „nawrócenia” nie bierze pod uwagę degradacji psychiki, która nie wytrzymała sytuacji skrajnego zagrożenia. O graniczności tego doświadczenia świadczą powojenne losy twórcy „Zwrotnicy” - życie w obłędzie i nieusuwalnym poczuciu prześladowania.

73 W. Rabski, Główna kwatera Korfantego, „Ilustrowany Kurier Codzienny” 14.05.1921, s. 2-3 oraz W. Gumplowicz, Karelia Wschodnia I i II, „Naprzód” 11.01.1922 i 12.01 .1922 , s. 4 i 3. Lentas wskazuje również artykuł Kornela Żywickiego Bolszewicy a religia. (Praktyki absolutyzmu oświeceniowego sowdepczyków) („Trybuna” 26.11.1921, s. 2-5) jako potencjalne źródło informacji, które trafiły do trzech tekstów Peipera. Por. B. Lentas, Tadeusz Peiper w Hiszpanii, s. 88. 
W obu omawianych szczegółowo przez Lentas przypadkach zapożyczenia mają różny charakter. W tekście na temat Górnego Śląska najwięcej podobieństw zdradza opis kwatery Wojciecha Korfantego. Natomiast w relacji na temat konfliktu fińsko-rosyjskiego o Karelię powtarza Peiper najważniejsze historyczno-geograficzne informacje na temat przedmiotu sporu oraz referuje potencjalne korzyści Finów z przyłączenia, a Rosjan $\mathrm{z}$ utraty spornych ziem. W obu przypadkach mamy do czynienia ze swoistym dokumentaryzmem, choć na zupełnie różnym poziomie. Opis kwatery, poza tym, że dowodzić miał naoczności relacji, ukazywał warunki, w jakich dochodziło do ważkich politycznych decyzji - zwyczajna sceneria, przypominająca ujętą $\mathrm{w}$ malarskim skrócie martwą naturę (obraz resztek posiłku na stole, notabene $\mathrm{w}$ opisie Peipera pisarza znacznie zmodyfikowany) tym silniej podkreślały spontaniczny charakter powstańczego zrywu. Z kolei argumentacja przytaczana przez Peipera za autorem tekstu o Karelii nie była w żadnym sensie własnością intelektualną jego autora. Polityczne racje stojące po obu stronach konfliktu były z pewnością wielokrotnie omawiane i przepowiadane przez korespondentów tamtych wydarzeń. Peiper najwyraźniej nie miał w tej sprawie poczucia żadnej nieuczciwości skoro w 1938 roku w artykule Odgłosy sprawy Górnego Ślaska w Hiszpanii w roku 1921 w okresie plebiscytu napisał:

Zamiast mówić od siebie [w artykułach o Górnym Śląsku pisanych dla gazet hiszpańskich], relacjonowałem ciągle artykuły prasy polskiej, układając je syntetycznie w wywód jak najmocniejszy i jak najbliższy myśleniu hiszpańskiemu. Gdy w naszej prasie nie znajdowałem potrzebnych mi w danej chwili sądów, mówiłem o głosach „opinii” przy czym przypisywałem sobie prawo zaliczać do tych głosów moje własne słowa ${ }^{74}$.

Choć Lentas jednoznacznie umieszcza kwestię metod Peipera korespondenta w kontekście plagiatu dziennikarskiego, udaje się jej przejść płynnie od spraw dotyczących publicystyki do sfery „naczelnych reguł twórczości polskiej awangardy, [wśród których] prócz kategorii konstrukcji, był zakaz naśladownictwa" [L 94]. W ten sposób nadaje swojemu wywodowi pozory koherencji, podporządkowując kolejne części książki tej samej niewypowiadanej nigdy wprost tezie: Peiper miał zwyczaj zatajać różne sprawy, a przede wszystkim rozmaite długi twórcze. Skoro korzystał z „zapożyczeń” w tekście dziennikarskim, mógł postąpić podobnie jako twórca koncepcji poetyckich, dopuszczając się wtórności, żeby nie powiedzieć: plagiatowości...

Nim autorka książki o Peiperze sformułuje ostateczną sugestię tego rodzaju, referuje jeszcze zagadnienie „Peiper wśród hiszpańskojęzycznych

74 Odgłosy sprawy Górnego Śląska w Hiszpanii w roku 1921 w okresie plebiscytu, „Zaranie Śląskie” 1938, nr 1. 
awangardzistów". W rozdziale pod tym tytułem jeszcze raz przepowiada wielokrotnie wykorzystywane argumenty, znane z tekstów Waśkiewicza i Casasa, mające dowodzić „pozbywania się śladów przeszłości” [L 103] przez Peipera. Przede wszystkim jednak gromadzi wszelkie możliwe, nawet najdrobniejsze tropy, mające potwierdzić liczne powiązania inicjatora „Zwrotnicy” z awangardą hiszpańską. Wskazuje między innymi, że w dziale „Corresponsales literarios de Ultra en El extranjero" [Korespondenci literaccy „Ultra” za granica] w stopce redakcyjnej pojawia się nazwisko i adres krakowski Peipera [L 113]. Nie bez satysfakcji konstatuje też: „Tuż obok nazwiska Polaka, które od maja 1921 roku przewija się tam regularnie, widnieje nazwisko innego obcokrajowca: Jorge Luisa Borgesa”. Można przypuszczać, że zwracając uwagę na umieszczone obok siebie nazwiska obu pisarzy, komentatorka pragnie zasugerować jakiś rodzaj magicznego ich „zrównania”... Gest ten daje się zinterpretować jako przejaw ulegania (post)kolonialnym schematom, tj. dowód postawy uzależniającej pozytywną ocenę przedstawiciela własnej nacji od tego, $\mathrm{w}$ jakim stopniu daje się on porównać z niekwestionowanym (jak Borges) światowym autorytetem w danej dziedzinie. Dalej formułuje Lentas domysł:

Najpewniej to dzięki Jahlowi [Władysław Jahl - polski malarz, związany z paryskim środowiskiem artystycznym, przebywający prawdopodobnie ${ }^{75} \mathrm{w}$ latach dwudziestych w Madrycie - A.K.], który jest jednym z trzech grafików awangardowego pisma obok Norah Borges i Rafaela Barradasa, Peiper stał się literackim współpracownikiem „Ultra” w Polsce [L 113].

Trudno nie wyprowadzić $\mathrm{z}$ tej uwagi dwóch wniosków i zarazem nie spostrzec, że podważają one wcześniejsze wywody autorki: po pierwsze pośrednictwo Jahla czyni wiarygodnym twierdzenie Peipera, że osobiście nie znał żadnego z twórców ultraistycznych; po drugie, że efekty owej „współpracy” nie były oszałamiające. Poza nazwiskiem Peipera w stopce świadczą o niej: informacja o czasopiśmie „Formiści”, recenzja książki Leona Chwistka Wielość rzeczywistości (w listopadzie 1921 roku) oraz wzmianka o tytułach czasopism „Nuż w bżuchu”, „Nowa Sztuka” i „Skamander" (w styczniu 1922 roku w dziale Publikacje otrzymane). Nic dziwnego, że sama autorka zauważa - mimowolnie dekonstruując swoją wcześniejszą retorykę - „Największym i najważniejszym jednak śladem Peipera w prasie awangardowej są publikacje w «Manomètre» z 1923 roku oraz w "Alfar» z roku 1929" [L 114]. Z trudem jednak uznać można opublikowanie trzech wierszy w pierwszym $\mathrm{z}$ tych pism za dowód współpracy poety z „hiszpańskojęzycznymi awangardzistami” (jak głosi tytuł podrozdziału); „Manomètre” było pismem francuskim. Co więcej, zarówno

75 Por. B. Lentas, Tadeusz Peiper w Hiszpanii, s. 238. 
druk w „Manomètre”, jak w „Alfarze” świadczy raczej o operatywności Peipera po powrocie do Polski niż dowodzi jakichś rzekomych intensywnych, choć zatajanych, kontaktów wcześniejszych. Na tle tej kontrowersji, prowokującej tak wiele rozmaitych opinii, często wypowiadanych tonem absolutnej pewności, sam Tadeusz Peiper jawi się jako osoba istotnie powściągliwa, lecz $\mathrm{w}$ innym sensie niż $\mathrm{w}$ przeświadczeniu licznych podejrzliwych: nie przypisuje sobie (choć przecież mógłby próbować) roli, której nie odegrał - uczestnika awangard zachodnich. Twórca „Zwrotnicy” rezerwuje dla siebie skromniejsze miano, nazywając się po prostu „synem tej samej epoki” („Z młodą Hiszpanią mamy tyle wspólnego, ile mieć muszą synowie tej samej epoki"76). To sformułowanie podpowiada, że zamiast dociekać domniemanych ukrytych zapożyczeń, wtórności, żeby nie powiedzieć: plagiatowości, trafniej jest przyjąć model analogii...

$\mathrm{Z}$ pozoru bierze go również pod uwagę Lentas, kiedy zauważa, że „analogie są uderzające” [L 132], cytując początek wypowiedzi Huidobry opublikowanej przez Peipera w „Nowej Sztuce”. Stwierdza jednak nieoczekiwanie: „Choć sprawa bezpośrednich związków teorii Peipera z kreacjonizmem jest ciekawa, to jednak wymagałaby osobnych studiów, na które nie ma miejsca w tej rozprawie" [L 133]. Rzeczywiście w ostatnim rozdziale jej książki zagadnienie związków teorii poezji Peipera z koncepcjami poetologicznymi formułowanymi przez innych europejskich awangardzistów zajmuje zaledwie sześć stron! W części zatytułowanej obiecująco Trzy poetyki: kreacjonizm, ultraizm, awangarda krakowska nie znajdziemy jednak analizy problematyzującej te trzy koncepcje poetyckie i zmierzającej do wyodrębnienia ich cech swoistych. W zamian Lentas poprzestaje na dalszym wykazywaniu „uderzających analogii” i „dość wyraźnych" podobieństw [L 138], stosując charakterystyczną dla obranej w całej książce metodę, tj. sięgając po sugestię i niedomówienie. Kiedy porównuje hasła twórcy „Zwrotnicy” z ustaleniami ultraistów, przywołuje wspominany wcześniej77 czteropunktowy program Borgesa i zauważa:

Jeśli pamiętamy artykuł Peipera Nowa poezja hiszpańska, postulaty Borgesa wydadzą nam się znajome i przez to zrozumiałe. Więcej nawet, czytając ten zwarty program, już na pierwszy rzut oka widzimy, że Peiper traktował nie tylko kreacjonizm, lecz także ultraizm jako punkt wyjścia swojej poezji i teorii [L 136].

Komentując w taki sposób, to znaczy nie określając jasno, o czym mówi - nadal o analogii, czy już o wpływie - autorka mimochodem wprowadza sugestię, że i tym razem być może dopuścił się Peiper „zapożycze-

76 Cyt. za T. Peiper, O wszystkim i jeszcze o czymś..., s. 188.

77 Por. przypis 55. 
nia".. Tymczasem manifest Borgesa ukazał się w Argentynie w grudniu 1921 roku, a artykuł Peipera o poezji hiszpańskiej w lutym 1922. Bardziej prawdopodobna niż hipoteza „zapożyczenia” wydaje się sytuacja pewnej niezwykłej równoległości ustaleń Argentyńczyka i Polaka, choć trudno przecież mówić o całkowitej zbieżności; u Borgesa nie ma tego, co uznać należy za differentia specifica koncepcji Peipera: bezwzględny wymóg całości i konstrukcji. Borges mówi jedynie o łączeniu „dwóch lub więcej obrazów w jeden” oraz o „serii metafor, a każda z nich ma swoją osobną możliwość sugerowania...”78. W istocie to właśnie ta cecha poezji ultraistycznej, w której, mówiąc słowami Peipera, „kolejne następstwo zdań nie nosi na sobie cechy konieczności”79, a „poszczególne części [można] dowolnie przestawić bez skutków istotnych dla całości utworu", umożliwiła mu bardzo swobodne potraktowanie wierszy młodych poetów hiszpańskich w przekładzie i dokonanie w ich tekstach „bezceremonialnych skreśleń"80, do czego przyznaje się w zakończeniu Tędy... Poza wszystkim jego ingerencje były wyrazem niezgody na ten typ wiersza Peiper nie potrafił zaakceptować poezji rozumianej jako seria metafor. Jeśli ideę odrealnienia poetyckich obrazów przejął od Huidobry, a uznanie zdania za podstawową jednostkę poetycką współdzielił z ultraistami, to zasada konstrukcji była z pewnością jego wynalazkiem, sposobem na uniknięcie formalnej dowolności.

Peiper okazał się w tych poszukiwaniach bardziej konsekwentny niż autor kreacjonizmu. W opinii Octavia Paza:

[Huidobro] nigdy nie nadał [...] definitywnej formuły [swojej koncepcji estetycznej]. Nie było to zresztą możliwe: Huidobro był błyskotliwy, ale nie potrafił rozwinąć idei, doprowadzić jej do ostatecznych konsekwencji, zbadać w rygorystyczny sposób i w końcu przemienić w prawdziwą teorię. Jego umysł był płodny i precyzyjny; Huidobro stale też formułował paradoksy. Wiele z nich trafiało w sedno, wiele olśniewało, po czym rozwiewało się bezpowrotnie ${ }^{81}$.

Zdaniem Paza chilijski poeta - w przeciwieństwie do Peipera - nie wykazywał żadnych chęci do rozwijania swoich idei. Z pewnego punktu widzenia można nawet powiedzieć, że polski teoretyk zrobił to za niego. Takie wyjaśnienie byłoby jednak zbyt proste i niesprawiedliwe - dla Peipera. Trafniejsze jest uznanie, że dla polskiego pisarza idea kreacjonistyczna była zaledwie jedną z wielu inspiracji, która za sprawą uporczywego odnawiania pewnego krytycznego toposu urosła w świadomości hi-

78 J.L. Borges, Ultraísmo.

79 T. Peiper, Nowa poezja hiszpańska. Cyt. za T. Peiper, O wszystkim i jeszcze o czymś..., ten i następny cytat ze s. 81.

80 T. Peiper, Tędy. Nowe usta, s. 314.

81 O. Paz, Altazor (Vicente Huidobro), „Literatura na Świecie” 2000, nr 7-8, s. 106. 
storyków literatury do rangi inspiracji podstawowej, źródłowej. Tymczasem nie mniej ważne były dla Peipera inne, przywiezione z Półwyspu Iberyjskiego tradycje - gongoryzm i greguerías. Obie w umyśle autora Żywych linii stopiły się w jeden poetycki zamysł. Ramón Gómez de la Serna, autor zbioru Greguerías z 1917 roku powiedział: „Greguería to dowcip plus metafora”. Hasło Komizm, dowcip, metafora odnajdujemy w Nowych ustach. Jednak Peiper nie powielał idei de la Serny. Choć inicjalne zdania $\mathrm{w}$ poematach rozkwitających przypominają niektóre paradoksalne greguerías ${ }^{82}$, idea autora $R a z$ polegała na innym rodzaju dowcipu, wykraczającym poza miarę pojedynczego zdania. Wzór dla uzyskania owej całości odnalazł w konceptyzmie barokowym.

Wiadomo, że w latach dwudziestych ubiegłego wieku poeci hiszpańscy fascynowali się poezją baroku. Trzechsetna rocznica śmierci Góngory celebrowana w 1927 roku stanowiła kulminację wielkiej fali zainteresowania dla tej poezji. Od tego wydarzenia pochodzi nazwa „pokolenia 1927"83. Wcześniej twórczość Góngory popularyzował poeta Ruben Darío. Dzięki tłumaczeniom Daríi ta niezwykła poezja czytana była również we Francji. W Polsce istnieje długa tradycja, aby interpretować poezję Peipera jako przykład nowoczesnej wersji poetyki barokowej84. Sam poeta przywoływał tradycję baroku rzadko. Jeśli jednak to czynił, zawsze odnosił się do niej z najwyższą estymą ${ }^{85}$. Kiedy analizujemy wiersze Peipera,

82 Por. W tabędziu tącza się aniot i wąz; Gtowa jest akwarium myśli; Gdzie jest biust krzewu? Cyt. za P. Sobolczyk, Españadiós, Toruń 2006, s. 100-101.

${ }^{83}$ Hiszpańska grupa artystyczna, której początki sięgają 1923 roku. Należeli do niej m.in. tacy twórcy, jak: Jorge Guillén, Federico García Lorca, Dámaso Alonso, Luis Cernuda, a w późniejszej fazie także Luis Buñuel i Salvador Dali.

84 Por. m.in. opinię Adama Ważyka (Kwestia gustu, Kraków 1966, s. 77): „Peiper był wielbicielem hiszpańskiego baroku i Gongóry. Lubował się w peryfrazach. Nie istniała dla niego bariera sztuczności albo też ustawiał ją sobie tak daleko, że nie mogłem jej dostrzec”; opinię Przybosia („Zwrotnica” Tadeusza Peipera, [w:] tenże, Sens poetycki, s. 166): „Być może nie godził się z ultraistami [...], ale - tak sądzę - jego teoria poezji nie powstałaby bez głębokiego przejęcia się i zrozumienia wielkiej poezji baroku i Gongóry” oraz jego charakterystyczne zdanie, wypowiedziane na temat sztuki Szósta! Szósta! (Dwie sztuki Tadeusza Peipera, [w:] tenże, Sens poetycki, s. 176): „Gongorystyczna hiszpańszczyzna Peipera święci tu swoje triumfy wykwintnisiostwa”; odniesienia do Gongóry w analizie poezji Peipera jako „poezji retoryki” w książce Jaworskiego (U podstaw awangardy..., s. 162, 174); wzmiankę Delaperrière (Barok w polskiej literaturze wspótczesnej: czyżby terapia?, [w:] taż, Dialog $z$ dystansu. Studia i szkice, Kraków 1998, s. 10). Zob. również: S. Jaworski, Nota biograficzna, [w:] T. Peiper, Tędy. Nowe usta, s. 420.

85 Por. np. Wiazania, „Kurier Literacko-Naukowy” 1936, nr 7, cyt za T. Peiper, O wszystkim $i$ jeszcze o czymś... ten i następne cytaty ze s. 423-424): „[...] barok był wielką epoką sztuki”; „Wspaniała złożoność barokowego dzieła sztuki, wyszukana mnogość i rozmaitość jego części składowych, wynalazczość form i lotność ich wzajemnych stosunków ha, to piękne!”; „Między epoką baroku a naszą istnieją pokrewieństwa”. 
z łatwością dostrzeżemy co najmniej kilka cech stylu barokowego. Jedną $\mathrm{z}$ nich jest wyraźne nagromadzenie metafor, $\mathrm{w}$ tym stopniu rzadko spotykane $\mathrm{u}$ innych poetów, współczesnych Peiperowi. Nie uszło ono uwadze badaczy, którzy komentowali je w rozmaity sposób. Irzykowski stworzył nawet nowy termin dla tego sposobu postępowania, nazywając je „metaphoritis"86 i sugerując, że ma ono wiele wspólnego z chorobą. W krytyce powojennej Ryszard Krynicki w skłonności Peipera do metafor rozpoznawał znak podobieństwa jego poetyckich poszukiwań do odkryć współczesnego nurtu psychologicznego znanego jako Gestaltpsychologie, czyli psychologii postaci (inaczej „całości”). Rzeczywiście, Peiper także posługiwał się pojęciem „całości”, kiedy opisywał korzyści z używania metafor. Pisał przecież:

[Metafora] jest bliższa naszym procesom myślowym. Widzimy rzeczy jako całości, pamiętamy zdarzenia jako całości, odczuwamy przeżycia jako całości, a mowa zwyczajna rozkłada je długo na kawały. Metaforyzacja nie notuje wprawdzie spraw takimi, jakimi one są, ale jej sposób łączenia pojęć ma w sobie coś z tych scalań, które dokonują się w procesach naszej świadomości ${ }^{87}$.

Jak wiemy z pism Baltasara Graciána, teoretyka doby baroku, często odwołującego się do Góngory, koncept oznaczał przede wszystkim nowe sposoby użycia zwyczajnych wyrazów, hojnie wprowadzane wyszukane gry słów, humor językowy, antytezy, przestawnie, hiperbole, a także cięte formy sądów, maksym i dowcipów... Konceptualistyczny sposób formułowania myśli można odnaleźć u Peipera, lecz tym, co najsilniej przypomina barokowy konceptyzm, są zaskakujące zestawienia, ustanawiające nowe, wielowymiarowe korespondencje między tym, co zestawiane, a zarazem gwarantujące upragnione przez poetę poczucie całości ${ }^{88}$. Dlatego cechą charakterystyczną tej poezji jest celowe zderzanie słów i pojęć należących do kompletnie różnych semantycznych pól. Ich jednoczesna i jednorazowa aktualizacja intrygowała i przykuwała uwage jako narzucona, zastanawiająca konieczność. Irzykowski odnotował trafnie, że Peiper w artykule $Z$ kraju słonej Wenery opisał hiszpański zwyczaj ludowy, polegający na obdarzaniu kobiet hiperbolicznymi komplementami, które „niepomysłowi

86 Por. K. Irzykowski, Metaphoritis i złota plomba, [w:] Walka o treść. Studia z literackiej teorii poznania, Warszawa 1929, [przedr. w:] K. Irzykowski, Pisma.

87 T. Peiper, Komizm, dowcip, metafora, pierwodruk: Tędy. Artykuty, Warszawa 1930. Cyt. za T. Peiper, Pisma wybrane, s. 160.

88 Por. jego przenikliwą i wiele mówiącą uwagę (Wiązania, „Kurier Literacko-Naukowy”. Cyt. za T. Peiper, O wszystkim i jeszcze o czymś..., s. 424): „Obfitość barokowa tylko wtedy jest przeładowaniem, gdy nie ma wewnętrznego uzasadnienia, w przeciwnym razie prowadzi do radującej jedności”. 
mężczyźni"89 mogli kupić wprost na ulicy - w postaci drukowanych piropos, czyli gotowych pochlebstw. Czyż nie był podobnym pochlebstwem wiersz o nodze - „Ten hymn z jedwabiu ponad okrucieństwem z cukru; / ta wstęga, która wykwita z miękkich liści trzewika [...]”?

Takie użycie języka nie było jednak możliwe w Polsce w codziennej mowie, choć być może nie byłoby niczym nadzwyczajnym na hiszpańskiej ulicy, nad którą unosił się duch Góngory. Przejmując coś z tej aury i próbując pisać w podobny sposób, w Polsce nie mógł liczyć Peiper na łatwą akceptację. Wielu pisarzy i krytyków nie wahało się nawet twierdzić, że ta poezja była zwyczajnie niezrozumiała. Inni, jak Julian Przyboś, wyjaśniali, że niejasne obrazy Peipera są nie do zrozumienia jedynie na poziomie struktur językowych, podczas gdy zawsze zawierają w sobie proste odniesienie do rzeczywistości. Uwaga Przybosia zawiera interesującą sugestię. Okazuje się, że inaczej niż proklamował Peiper w swojej teorii, w utworach poetyckich nie oddalał się tak bardzo od realnego i niezwykle zmysłowo odczuwanego świata ${ }^{90}$. Mówiąc jeszcze prościej, ta sytuacja dokumentuje jeszcze jedną rozbieżność pomiędzy kreacjonistycznymi implikacjami teorii Huidobry a ideą ukrytej korespondencji wszystkich elementów świata, zawartą $\mathrm{w}$ filozofii barokowego konceptyzmu i... w poezji Peipera ${ }^{91}$.

\section{Postscriptum}

Z Huidobrą łączy polskiego poetę natomiast z pewnością inna sprawa - obaj doświadczyli posądzenia o wtórność. Chilijczyk w jawnych zarzu-

89 Por. Zdobnictwo w poezji, [w:] Walka o treść, Warszawa 1929, [przedr. w:] K. Irzykowski, Pisma, s. 47.

90 Zob. J. Grądziel-Wójcik, Drugie oko Tadeusza Peipera. Projekt poezji nowoczesnej, Poznań 2010.

91 Ten dylemat odzwierciedla w jakiejś mierze rozdarcie opisujące innego poetę Stéphane'a Mallarmégo, często przywoływanego przy okazji analiz poezji i myśli Tadeusza Peipera. Francuski poeta reprezentuje krańcowy sposób myślenia o poezji. Dlatego z pewnego punktu widzenia za jego polskiego odpowiednika uważać można Peipera. Jednak, jak zwykle czyniąc takie porównania, należy zachować dużą ostrożność i nie zapominać o ich ograniczonej mocy. Poza wszystkim, paradoksalnie zestawianie Mallarmégo i Peipera dostarcza jeszcze jednej okazji do zmierzania stopnia zbieżności dróg myślenia tego ostatniego z tym wszystkim, co dał mu kontakt z kulturą hiszpańską. Jak się wydaje, bliżej mu bowiem jednak do Góngory niż do Mallarmégo. Warto w tym miejscu przywołać Hugo Friedricha, który stwierdził: „Aby rozwikłać niejasność Góngory, wystarczy w istocie uporządkować składnię i zredukować peryfrazy do tego, co one opisują. U Mallarmégo wygląda to wszystko zupełnie inaczej”. Istotnie, identyczna zasada towarzyszy zawiłym i wypracowanym poematom Peipera, które często odsyłają do bardzo prostego i konkretnego fragmentu rzeczywistości bądź jej stanu. 
tach, ostatecznie oddalonych ${ }^{92}$, Polak w sposób zawoalowany i w sugestiach ponawianych do dzisiaj. Można odczytywać w uporczywym trwaniu tej sytuacji znak ironii losu, a nawet formę karmicznej zapłaty za współudział Peipera w surowym osądzeniu innego poety innej awangardy - Stanisława Brucza, związanego z „Almanachem Nowej Sztuki”, autora intrygujących tekstów o poezji ${ }^{93}$. Brucz faktycznie dopuścił się plagiatu. Przetłumaczył z rosyjskiego i opublikował w 1925 roku pod własnym nazwiskiem opowiadanie Aleksandra Grina (Aleksandra Stepanowicza Hryniewskiego). Dlaczego tak zrobił, nie wiadomo. Wiadomo jedynie, zgodnie z relacją przyjaciela ${ }^{94}$, że zaproponowano mu napisanie opowiadania do czasopisma "Ilustracja” i obiecano duże honorarium, za które chciał sobie kupić nowe buty. Cieszył się, gdyż chodził w zniszczonych. Kiedy sprawa się wydała - wskutek demaskującej notki Mieczysława Grydzewskiego w „Wiadomościach Literackich”95 - Brucz zniknął. Oburzenie było powszechne, dotarło z pewnością do Peipera, który skrzętnie podchwycił temat. Kiedy $\mathrm{z}$ typowym dla siebie temperamentem omawiał krytycznie pewien utwór Brucza, wytknął mu przy okazji „wyjątkowo bezczelny plagiat"96... Tę historię - dzieje faktycznego, choć mało istotnego plagiatu - można by traktować tylko jako jedną z wielu międzywojennych anegdot, gdyby nie to, że w owym 1925 roku Brucz miał właśnie objąć funkcję redaktora naczelnego nowego tygodnika „Comoedia”97. Planowane czasopismo miało szansę z jednej strony skupić wokół siebie rozproszone środowisko awangardystów idących inną drogą niż Peiper, a z drugiej realnie zagrozić dominacji „Wiadomości Literackich” na rynku... Brucz wrócił w latach trzydziestych, w środowisku „Wiadomości

92 Spór i wzajemne oskarżenia wybuchły między Huidobrą a Pierre’em Reverdym. Aż do lat sześćdziesiątych krytyka była skłonna uznawać racje Francuza i jemu przypisywać pierwszeństwo w wynalezieniu kreacjonizmu. Kontrowersję rozstrzygnęło odnalezienie tomu Chilijczyka z 1916 roku, a więc z czasów, kiedy nie znał on jeszcze Reverdy'ego. Sprawę nieco szerzej omawia Beata Lentas (Peiper w Hiszpanii, s. 35-36 oraz 244. Zob. też G. de Torre, La polemica del creacionismo: Huidobro y Reverdy, [w:] tenże, Ficción, Buenos Aires 1962, [przedr. w:] R. de Corta, Vicente Huidobro y el creacionismo, Madrid 1975; B. Arenas, Vicente Huidobro y el creacionismo, [w:] tenże, Obras completas de Vicente Huidobro, Santiago 1964; R. Admussen y R. de Costa, Huidobro, Reverdy and the editio princeps of El espejo de agua, „Comparative Literature” 1972, z. 2.

${ }_{93}$ Sztuka i rzecz, „Nowa Kultura” 1924, nr 1; Zarys nowej poetyki, „Almanach Nowej Sztuki” 1924, nr 2.

94 A. Ważyk, Sprawa Stanisława Brucza, „Literatura” 1978, nr 3, s. 8.

95 Czelna kradzież, „Wiadomości Literackie” 1925, nr 52, s. 3.

96 Zob. T. Peiper, Nie gejzery. Ggejsze!, „Echo Tygodnia” 1929, styczeń, [przedr. w:] tenże, Tędy. Nowe usta, s. 273.

97 Por. A. Ważyk, Sprawa Stanisława Brucza. 
Literackich" próbowano mu pomagać i zadośćuczynić98, ale pozostał złamany do końca życia99. A heterogenicznemu Ruchowi Nowej Sztuki nie dane było podjąć bardziej zrygoryzowanej i uporządkowanej dyskusji z koncepcją Peipera...

98 Jeszcze przed powrotem Brucza ukazały się artykuły Stefana Napierskiego (Zapoznany poeta - S. Brucz, „Epoka 1927, nr 333; Niedocenieni poeci, „Wiadomości Literackie” 1928, nr 8), który wcześniej, jeszcze zanim wybuchła afera z plagiatem, pisał o koncepcjach Brucza nieprzychylnie (O rewolucyjności w poezji, „Wiadomości Literackie” 1924, nr 15).

99 Zob. W. Woźniak, Doświadczenia poetyckie Stanisława Brucza, [w:] S. Brucz, Wybór poezji, wybrał i wstępem opatrzył W. Woźniak, Warszawa 1987. 
